\title{
Shikonin Suppresses Human T Lymphocyte Activation through Inhibition of IKK $\beta$ Activity and JNK Phosphorylation
}

\author{
Ting Li, Fenggen Yan, Rui Wang, Hua Zhou, and Liang Liu \\ State Key Laboratory of Quality Research in Chinese Medicine, Macau Institute for Applied Research in Medicine and Health, \\ Macau University of Science and Technology, Avenida Wai Long, Taipa, Macau
}

Correspondence should be addressed to Liang Liu; lliu@must.edu.mo

Received 5 February 2013; Accepted 30 March 2013

Academic Editor: Il-Moo Chang

Copyright (C) 2013 Ting Li et al. This is an open access article distributed under the Creative Commons Attribution License, which permits unrestricted use, distribution, and reproduction in any medium, provided the original work is properly cited.

\begin{abstract}
The key role of $\mathrm{T}$ cells has been elaborated in mediating immune responses and pathogenesis of human inflammatory and autoimmune conditions. In the current study the effect of shikonin, a compound isolated from a medicinal plant, on inhibition of T-cell activation was firstly examined by using primary human T lymphocytes isolated from buffy coat. Results showed that shikonin dose dependently suppressed T-cell proliferation, IL-2 and IFN- $\gamma$ secretion, CD69 and CD25 expression, as well as cell cycle arrest activated by costimulation of PMA/ionomycin or OKT-3/CD28 monoclonal antibodies. Moreover, these inhibitory responses mediated by shikonin were found to be associated with suppression of the NF- $\kappa \mathrm{B}$ signaling pathway via inhibition of the IKK $\alpha / \beta$ phosphorylation, I $\kappa$ B $-\alpha$ phosphorylation and degradation, and NF- $\kappa$ B nuclear translocation by directly decreasing IKK $\beta$ activity. Moreover, shikonin suppressed JNK phosphorylation in the MAPKs pathway of T cells. In this connection, we conclude that shikonin could suppress T lymphocyte activation through suppressing IKK $\beta$ activity and JNK signaling, which suggests that shikonin is valuable for further investigation as a potential immunosuppressive agent.
\end{abstract}

\section{Introduction}

The red naphthoquinone pigment shikonin (Figure 1(a)) is the major bioactive component in the roots of Lithospermum erythrorhizon Sieb. et Zucc. (Boraginaceae), which possesses a number of medical properties like relieving measles, macular eruptions, sore throat, burns, and carbuncles. According to the theories of Chinese and Korean traditional medicine, it is believed to possess properties of removing heat from the blood and detoxification [1] and claimed to be beneficial for burns anal ulcers, haemorrhoids, infected crusts, bedsores, external wounds, and oozing dermatitis [2]. It was also reported to have anti-inflammatory, antithrombotic, and antitumor action [3-5]. These effects were produced by inhibition of proteasome in primary macrophages, downregulation of NF- $\kappa$ B/MAPK activation [6], prevention of NF$\kappa \mathrm{B}$ to DNA in RAW264.7 cell line [7], suppression of gene expression of TNF- $\alpha$, IL- $1 \beta$ and IL-4, chemokines CCL4 and CCL8, as well as the inflammatory modulators NFATC3 and PTGS2 [8]. In addition, shikonin showed to inhibit maturation of bone marrow-derived dendritic cells in vitro
[2]. However, there is no report about the action and mechanism of shikonin on $\mathrm{T}$ cells, a dominant cell population for mediating immune and inflammatory responses in humans.

$\mathrm{NF}-\kappa \mathrm{B}$ is a ubiquitous and well-characterized transcriptional factor in cellular signaling during T-cell activation, which regulates a large number of genes involving immune, inflammatory, and antiapoptotic responses [9]. In resting $\mathrm{T}$ cells, NF- $\kappa \mathrm{B}$ is bound to $\mathrm{I} \kappa \mathrm{B} \alpha$ in cytoplasm, existing as a heterodimer composed by $\mathrm{p} 65$ and $\mathrm{p} 50$ proteins. When $\mathrm{T}$ cells are activated by stimuli, I $\kappa$ B kinase (IKK) and two sitespecific critical serine residues of $\mathrm{I} \kappa \mathrm{B} \alpha$ (Ser32, Ser36) are phosphorylated. Subsequently, the phosphorylation form of $\mathrm{I} \kappa \mathrm{B} \alpha$ is hence ubiquitinated, cleaved by the $26 \mathrm{~S}$ proteasome, and then degraded. Hence then NF- $\kappa$ B is released and translocated into the nucleus of cells, where it binds to $\kappa \mathrm{B}$ enhancer element of DNA, and induces transcription of many inflammatory mediators [10], and finally leads to activation of $\mathrm{T}$ cells. Therefore, due to the key role of NF- $\kappa \mathrm{B}$ signaling in regulating T-cell activation and immune response, it is one of the important strategies to develop NF- $\kappa \mathrm{B}$ signaling for drug discovery in the past decade [11-13]. Although NF- $\kappa \mathrm{B}$ 
<smiles>CC(C)=CCC(O)C1=CC(=O)c2c(O)ccc(O)c2C1=O</smiles>

(a)

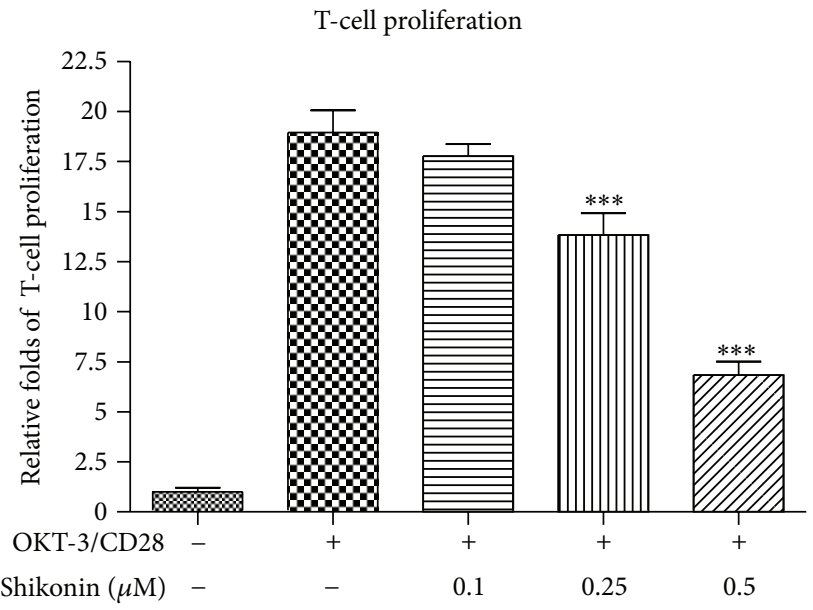

(c)

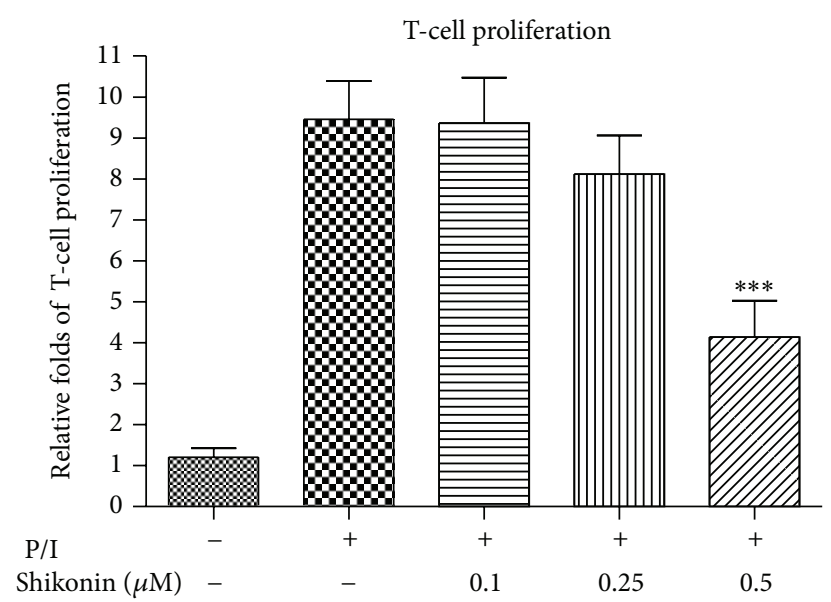

(b)

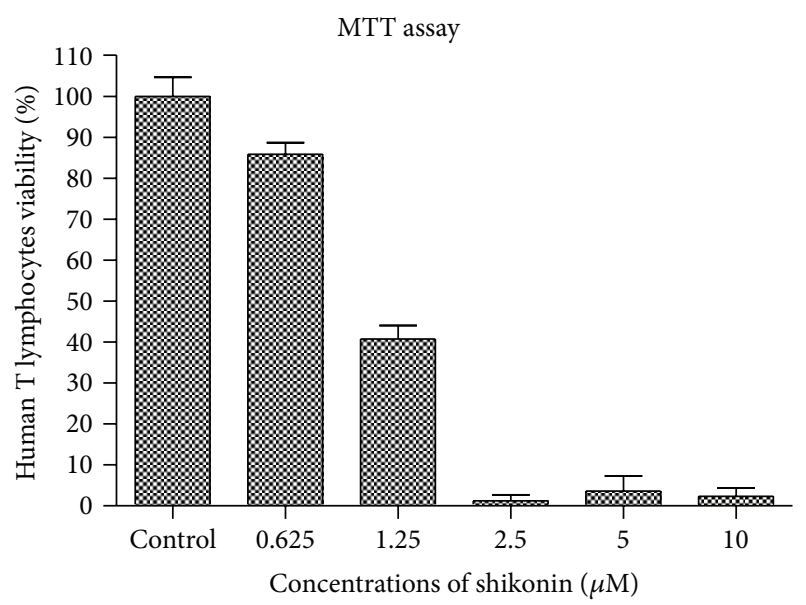

(d)

FIGURE 1: Effect of shikonin on suppression of cell proliferation and its cytotoxicity in human T lymphocytes. Chemical structure of shikonin (a). Effect of shikonin on T lymphocytes proliferation stimulated by PMA/ionomycin (b) or OKT-3/CD28 (c). Human T cells (10 $5 /$ well) were pretreated with the indicated concentrations of shikonin for $2 \mathrm{~h}$ and then activated with PMA $(20 \mathrm{ng} / \mathrm{mL}) /$ ionomycin $(1 \mu \mathrm{M})(\mathrm{P} / \mathrm{I})$ or with the coated OKT-3 $(5 \mu \mathrm{g} / \mathrm{mL}) / \mathrm{CD} 28(1 \mu \mathrm{g} / \mathrm{mL})(\mathrm{OKT}-3 / \mathrm{CD} 28)$ for $72 \mathrm{~h}$. BrdU was added to the cells for $14 \mathrm{~h}$ incubation before the end of cell culture, and then the amount of BrdU incorporation was measured by using plate reader at $450 \mathrm{~nm}$. Data are expressed as relative folds of BrdU incorporation of the controlled cells and represent the mean \pm SEM of three independent experiments. Cytotoxicity of shikonin on human T lymphocytes (d). The cells $\left(10^{5} /\right.$ well) were treated with shikonin at the indicated concentrations for 3 days, and then MTT reagent was added to the cells for $4 \mathrm{~h}$ of incubation followed by addition of solubilization buffer. The absorbance was then read at $570 \mathrm{~nm}$. Data are expressed as the percentage of absorbance of controlled cells and represent the mean \pm SEM of three independent experiments.

activity can be suppressed by inhibition of $26 \mathrm{~S}$ proteasome, IKK activity, or interfering with binding of NF- $\kappa$ B to DNA, IKK $\beta$ activity has been evident of playing the pivotal role in regulating NF- $\kappa \mathrm{B}$ activation. As such, screening selective IKK $\beta$ inhibitors would be an effective strategy for developing anti-inflammatory therapeutics [13].

In addition, the mitogen-activated protein kinases (MAPKs), a family of serine/threonine, have been known as the central pathway of T-cell activation and one of the most attractive targets for intervening inflammatory and autoimmune conditions. MAPKs contain the signature sequence -TXY-, where $\mathrm{T}$ and $\mathrm{Y}$ are threonine and tyrosine, and $\mathrm{X}$ is glutamate, proline, or glycine, in ERK, JNK, or p38, respectively [14]. To date, four components of MAPKs have been identified, that is, the extracellular signal-regulated kinases (ERK1/2), c-Jun NH2-terminal kinase (JNK-1/2/3), p38 $(\mathrm{p} 38 \alpha / \beta / \gamma / \delta)$, and ERK5. Among them, p38 and JNK can be activated by cellular stresses, called as stress-activated MAPKs. Taken together, both NF- $\kappa \mathrm{B}$ and MAPKs are the major signaling pathways involving $\mathrm{T}$-cell activation and the attractive targets for developing anti-inflammation and immunomodulation drugs.

Shikonin has been previously reported effectively for anti-inflammation, antithrombosis and antitumor through downregulation of $\mathrm{NF}-\kappa \mathrm{B} / \mathrm{MAPK}$ activation in primary macrophages, while the effect of shikonin on human T-cell activation has never been reported. In the current study we demonstrated the action of shikonin on the cell proliferation, 
cell cycle, expression of cell surface activation marker, and modulation of NF- $\kappa \mathrm{B}$ and MAPKs signaling in human T lymphocytes.

\section{Materials and Methods}

2.1. Drugs and Reagents. Shikonin of $>98 \%$ purity verified by HPLC was obtained from Merck \& Co. (Rahway, NJ, USA). Pan T-Cell Isolation Kit II was purchased from MACs (Earhart Avenue, CA, USA). Anti-human Phycoerythrin (PE)-CD3 antibody and other antibodies of fluorescein isothiocyanate (FITC)-CD25, FITC-CD69, FITC-CD71, NF- $\kappa$ B, and OKT3 antibody were from BD Pharmingen Inc. (San Diego, CA, USA). CD28 monoclonal antibody was purchased from eBioscience (San Diego, CA, USA). Phorbol 12myristate 13-acetate (PMA) and ionomycin were obtained from Sigma and Calbiochem, respectively. FLAG-tagged IKK $\beta$ wildtype (wt) was gift from Tom Gilmore (Boston University) and checked by standard DNA sequencing. The primary antibodies used in the current study were rabbit antibodies specific for $\mathrm{I} \kappa \mathrm{B} \alpha$, IKK- $\alpha / \beta, \mathrm{p}-\mathrm{IKK} \alpha / \beta$, and $\mathrm{p}$ $\mathrm{I} \kappa \mathrm{B} \alpha^{\mathrm{ser} 32}$ (Cell signaling, USA), mouse antibodies specific for actin (Santa Cruz, USA). Both IL- 2 and IFN- $\gamma$ ELISA kit were purchased from Invitrogen (Carlsbad, CA, USA).

2.2. Human T-Cell Isolation, Purification, and Stimulation. Human peripheral blood T lymphocytes were isolated from buffy coat blood, based on the method described previously [15]. Briefly, the buffy coat blood obtained from Macau blood transfusion center was mixed with normal saline and then transferred to Ficoll-Paque (Amersham Biosciences, USA) in $50 \mathrm{~mL}$ tubes. The mixture was centrifuged at $350 \mathrm{~g}$ for $35 \mathrm{~min}$ to separate the blood into layers. The layer of mononuclear cells was collected, and then all of cells were purified by MACs pan T-cell kit. Human T lymphocytes were cultured in RPMI 1640 medium supplemented with 10\% fetal bovine serum (FBS). To stimulate T lymphocyte activation, two sets of costimulators, that is, $20 \mathrm{ng} / \mathrm{mL}$ PMA plus $1 \mu \mathrm{M}$ ionomycin (PMA/ionomycin) or immobilized $5 \mu \mathrm{g} / \mathrm{mL}$ OKT-3 antibody plus $1 \mu \mathrm{g} / \mathrm{mL}$ CD28 antibody (OKT-3/CD28), were used. According to the different purposes of the experiments, one set of costimulators from the above two was employed in each experiment, with different time intervals of stimulation and cell culture.

2.3. T Lymphocyte Proliferation and Cytotoxicity Assay. T lymphocyte proliferation assay was conducted by cell proliferation kit (Roche, USA) according to the manufacturer's instruction. Briefly, $100 \mu \mathrm{L}$ human $\mathrm{T}$ lymphocytes $(1 \times$ $10^{6} / \mathrm{mL}$ ) were cultured in 96-well plates in triplicate in 1640 medium plus 10\% FBS. The cells were then stimulated with $20 \mathrm{ng} / \mathrm{mL}$ PMA plus $1 \mu \mathrm{M}$ ionomycin or coated $5 \mu \mathrm{g} / \mathrm{mL}$ OKT-3 plus $1 \mu \mathrm{g} / \mathrm{mL}$ CD-28 in the presence or absence of shikonin for $72 \mathrm{~h}$. BrdU was added to the cells at final concentration of $10 \mu \mathrm{M}$ and then following incubated for another $14 \mathrm{~h}$. BrdU can incorporate into the dividing cells in their DNA; thus, quantification of BrdU incorporation shows the degree of cell proliferation. In our current experiments, BrdU was determined by ELISA method, and data were obtained from three independent experiments.

MTT (3-(4,5-dimethylthiazol-2-yl)-2,5-diphenyl tetrazolium bromide) was employed to determine the cytotoxicity as described previously [16]. Briefly, $100 \mu \mathrm{L}$ human $\mathrm{T}$ lymphocytes $\left(1 \times 10^{5} /\right.$ well $)$ were cultured in triplicate in a 96-well plate in RPMI 1640 medium plus 10\% FBS for $72 \mathrm{~h}$. MTT $(5 \mathrm{mg} / \mathrm{mL})$ was added for $4 \mathrm{~h}$ incubation, and then a solvent (10\% sodium dodecyl sulfate (SDS), $50 \% \mathrm{~N}, \mathrm{~N}-$ dimethyl formamide, $\mathrm{pH}$ 7.2) was added to dissolve the purple precipitate. $A_{570 \mathrm{~nm}}$ was determined from each well on the next day. The percentage of cell viability was calculated using the following formula: Cell viability (\%) $=A_{\text {treated }} / A_{\text {control }} \times$ 100. Data reported represent three independent experiments.

2.4. Enzyme-Linked Immunosorbent Assay. The level of IL-2 and IFN- $\gamma$ secreted by the activated human T lymphocytes was evaluated by using IL- 2 and IFN- $\gamma$ human enzyme-linked immunosorbent assay (ELISA) method (Invitrogen, USA). In brief, cells $\left(1 \times 10^{5} /\right.$ well $)$ were incubated in the presence or absence of shikonin for $2 \mathrm{~h}$ at different concentrations, and then the cells were stimulated with $5 \mu \mathrm{g} / \mathrm{mL}$ OKT-3 plus $1 \mu \mathrm{g} / \mathrm{mL}$ CD2 8 or $20 \mathrm{ng} / \mathrm{mL}$ PMA plus $1 \mu \mathrm{M}$ ionomycin for another $48 \mathrm{~h}$. The culture supernatants were collected, and then concentration of IL-2 in the supernatants was determined by ELISA method according to the manufacturer's instructions. All samples were determined in triplicate. Data were obtained from three independent experiments.

2.5. T Lymphocyte Surface Marker, Intercellular Protein, and Cell Cycle Analysis. Flow cytometry was employed to evaluate the expressions of T lymphocyte surface markers, including $\mathrm{CD} 25$, CD69, and CD71, according to the previously described method [17]. Human T lymphocytes $\left(1 \times 10^{6} /\right.$ well $)$ were pretreated with shikonin for $2 \mathrm{~h}$ and then stimulated with PMA $(20 \mathrm{ng} / \mathrm{mL})$ plus ionomycin $(1 \mu \mathrm{M})$ [17]. For determination of CD69 expression, the cells were stimulated for $24 \mathrm{~h}$ by PMA plus ionomycin; for determination of the expressions of CD25 and CD71 the cells were cultured with stimulators and shikonin for $48 \mathrm{~h}$. At the end of cultures, the cells were harvested and washed with PBS. Cells were then incubated with specific antibodies in the combination of anti-CD69-FITC and anti-CD3-PE, anti-CD25-FITC and anti-CD3-PE, or anti-CD71-FITC and anti-CD3-PE (BD Pharmingen, San Diego, CA, USA), stained for $30 \mathrm{~min}$ at room temperature in the dark, and then fixed with $4 \%$ PFA paraformaldehyde. On the following day, samples were analyzed on FACS Calibur Flow Cytometer using CellQuest software (BD Biosciences, San Diego, CA, USA). The compensation standards were composed of the separate tubes of cells stained with positive single-color antibodies for each of the fluorochromes.

For analysis of intercellular NF- $\kappa \mathrm{B}$ expression using flow cytometry, the cells were incubated with shikonin for $2 \mathrm{~h}$, and then fixed immediately by cytofix buffer after the stimulated by PMA plus ionomycin; subsequently the cells were harvested followed by permeabilization, incubated on ice for $30 \mathrm{~min}$, washed by PBS for three times, and then resuspended in stain buffer containing NF- $\kappa \mathrm{B}$ antibody and 
incubated for $60 \mathrm{~min}$ avoiding light. Finally, the cells were washed by stain buffer and analyzed by flow cytometer.

For analysis of cell cycle, human Tlymphocytes $\left(10^{6}\right)$ were treated with shikonin for $2 \mathrm{~h}$ and then cultured with or without PMA $(20 \mathrm{ng} / \mathrm{mL})$ plus ionomycin $(1 \mu \mathrm{M})$ for $72 \mathrm{~h}$. After the culture, cells were harvested by centrifugation, washed by PBS, fixed by $70 \%$ ethanol, and stained by PI (Propidium Iodide, BD Pharmingen, San Diego, CA, USA) for $30 \mathrm{~min}$ at room temperature, and then the cell cycle analysis was measured as the previously reported method after the cells were washed by PBS for three times [18].

2.6. Analyses of Cellular Protein Expressions by Using Western Blotting. For detection of $\mathrm{I} \kappa \mathrm{B} \alpha$, phosphorylation forms of $\mathrm{IKK} \alpha / \beta$, total IKK $\alpha / \beta$, phosphorylation forms of JNK (PJNK), total JNK, phosphorylation forms of ERK1/2 (PERK1/2), total ERK1/2, phosphorylation forms of p38 (P-p38) and total p38 kinase from whole cellular proteins, the human T lymphocytes $\left(4 \times 10^{6} /\right.$ well $)$ were preincubated with different concentrations of shikonin for $60 \mathrm{~min}$. In determining the phosphorylation form of $\mathrm{I} \kappa \mathrm{B} \alpha$, the human T lymphocytes $\left(4 \times 10^{6} /\right.$ well $)$ were preincubated with different concentrations of shikonin together with $100 \mu \mathrm{g} / \mathrm{mL} \mathrm{N}$-acetyl-leucylleucyl-norleucinal (ALLN) (Calbiochem, USA) for $60 \mathrm{~min}$. The cells were then incubated with PMA $(20 \mathrm{ng} / \mathrm{mL})$ plus ionomycin $(1 \mu \mathrm{M})$ for another $60 \mathrm{~min}$ and finally harvested. The harvested $\mathrm{T}$ lymphocytes were lysed with lysis buffer (50 mM Tris-HCl, pH 7.5, 250 mM NaCl, 5 mM EDTA, 1 mM DTT, $1 \%$ Triton, $50 \mathrm{mM} \mathrm{NaF,} 1 \mathrm{mM}$ sodium orthovanadate, $0.5 \mathrm{mM}$ PMSF and $1 \times$ protease inhibitor mix (Roche, USA) to produce whole cellular proteins. The whole cellular proteins were then subjected to electrophoresis in 10\% SDS/PAGE and to immunoblotting as mentioned above. The primary antibodies used in this study were rabbit antibodies specific for $\mathrm{I} \kappa \mathrm{B} \alpha, \mathrm{P}-\mathrm{I} \kappa \mathrm{B} \alpha^{\mathrm{ser} 32}, \mathrm{IKK} \alpha / \beta$ and P-IKK $\alpha / \beta$, P-JNK (Thr183/Try185), JNK, P-ERK1/2 (Thr220/Try204), ERK, Pp38 (Thr180/Try182), p38 (Cell Signaling, USA), and mouse antibodies specific for actin (Santa Cruz, USA).

2.7. Transfection and Immunoprecipitation. The transfection assay was conducted according to the manual of lipofectamine LTX (Invitrogen, USA). Briefly, on the day before transfection, trypsinize and count the HEK293T cells, $5 \times 10^{5}$ cells per well were seeded in $1.5 \mathrm{~mL}$ of complete DMEM growth medium. For each well of cells to be transfected, $1.25 \mu \mathrm{g}$ of FLAG-IKK $\beta$ wt plasmid was diluted in $500 \mu \mathrm{L}$ of OptiMEM Reduced Serum Media without serum. For each well of cells, $1.25 \mu \mathrm{L}$ of PLUS was added into the above diluted Opti-MEM : DNA solution, mixed gently, and incubated for $5 \mathrm{~min}$ at room temperature. Subsequently, lipofectamine LTX Reagent was added into the above solution and then mixed gently and incubated 30 minutes at room temperature to form DNA-lipofectamine LTX Reagent complexes. After 30 minute incubation, $500 \mu \mathrm{L}$ of the DNA-lipofectamine LTX Reagent complexes was directly added to each well containing cells and mixed gently. The cells were incubated at $37^{\circ} \mathrm{C}$ in a $\mathrm{CO}_{2}$ incubator for $24 \mathrm{~h}$ after transfection.
IKK $\beta$ recombinant protein was pull down by using Flag tagged protein immunoprecipitation Kit (Sigma) according to the manual. In brief, after transfection with Flag-IKK $\beta$ wt for $24 \mathrm{~h}$, HEK293T cells were collected and washed by PBS for twice. The cell lysates were prepared by incubation with lysis buffer for $15 \mathrm{~min}$ on ice and then centrifuged for $10 \mathrm{~min}$ at $12,000 \times \mathrm{g}$. The resin was prepared according to the manual, and the cell lysates were added to the resin and agitated for overnight at $4^{\circ} \mathrm{C}$. The resin was collected by centrifuging for $30 \mathrm{sec}$ at $8200 \times \mathrm{g}$ and then washed by wash buffer for 3 times. Finally, the Flag-IKK $\beta$ wt was eluted by competition with $3 \times$ Flag peptide and stored in $-80^{\circ} \mathrm{C}$ for conducting IKK $\beta$ kinase assay.

2.8. IKK Kinase Assay. To determine the direct effect of shikonin on IKK $\beta$ activity, the IKK $\beta$ kinase assay was performed. In brief, both GST-I $\kappa$ B- $\alpha$ substrate, FLAG-IKK- $\beta$ wt recombinant protein, and ATP were incubated with or without shikonin at $30^{\circ} \mathrm{C}$ for $30 \mathrm{~min}$. The mixture was analyzed by $10 \%$ SDS-polyacrylamide gel electrophoresis (SDS-PAGE) and then electrotransferred onto nitrocellulose membranes. The nitrocellulose membranes were blocked by $5 \%$ dried milk for $60 \mathrm{~min}$ and then incubated with $\mathrm{P}-\mathrm{I} \kappa \mathrm{B} \alpha$ for overnight at $4^{\circ} \mathrm{C}$. Next day, the membranes were washed with TBS-T again and further incubated with HRP-conjugated secondary antibodies for $60 \mathrm{~min}$. The blots were developed using ECL Western Blotting Detection Reagents (Amersham Biosciences).

2.9. Statistical Analysis. Data are expressed as means \pm SEM. One-way ANOVA or unpaired Student's $t$-test was used to determine the significance of difference; a value of $P<0.05$ was considered statistically significant.

\section{Results}

3.1. Shikonin Inhibits Human T Lymphocyte Proliferation. Optimal $\mathrm{T}$ lymphocyte proliferation requires two signals, one is provided by the antigen-specific T-cell receptor (TCR) complex and the other is the costimulatory receptor CD28. In the current study, the immobilized OKT3 $(5 \mu \mathrm{g} / \mathrm{mL})$ plus CD28 $(1 \mu \mathrm{g} / \mathrm{mL})$ antibodies in 96-well plates or PMA $(20 \mathrm{ng} / \mathrm{mL})$ plus ionomycin $(1 \mu \mathrm{M})$ were employed to activate $\mathrm{T}$ cells, and the hallmarks of the cell activation could be observed, namely, cell proliferation and secretion of IL-2 and IFN- $\gamma$. Therefore, we firstly examined the effect of shikonin on human T-cell proliferation, and the results showed that shikonin could suppress the T-cell proliferation induced by OKT-3/CD28 or PMA/ionomycin in a dose-dependent manner (Figures 1(b) and 1(c)). To determine whether the suppressive effect of shikonin on human T lymphocyte proliferation is resulted from the cytotoxicity of the compound, MTT method was employed to evaluate the viability of $\mathrm{T}$ cell in the experiment. As shown in Figure 1(d), there is no significant difference on the cell viability between shikonintreated and nontreated cells at $0.625 \mu \mathrm{M}$, so that $0.5 \mu \mathrm{M}$ shikonin was used as high concentration for further study.

3.2. Shikonin Inhibits $I L-2$ and IFN- $\gamma$ Secretion in Human $T$ Lymphocytes. $\mathrm{T}$ cell proliferation depends on cytokines 


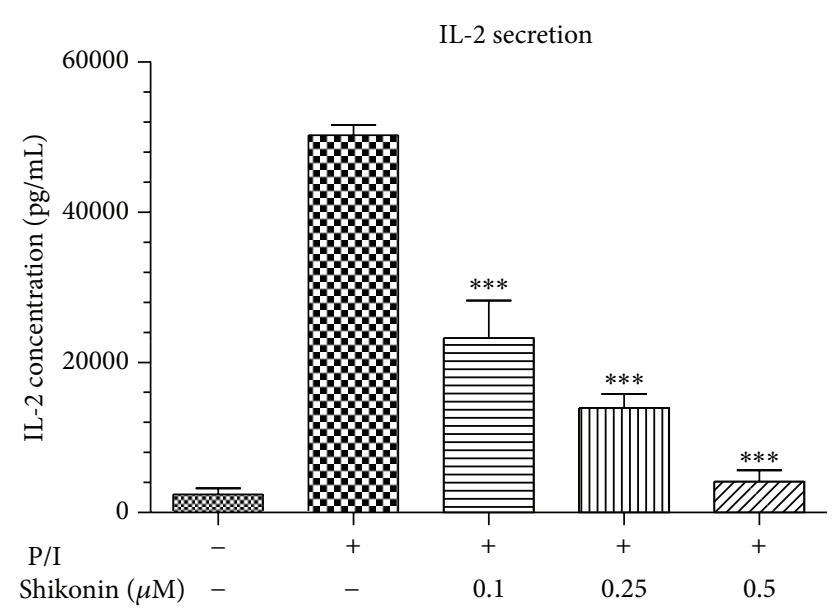

(a)

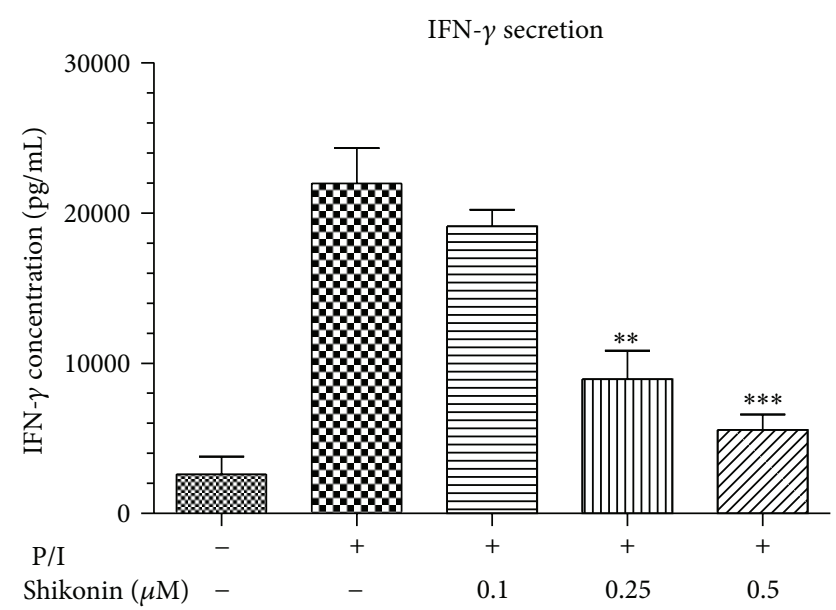

(c)

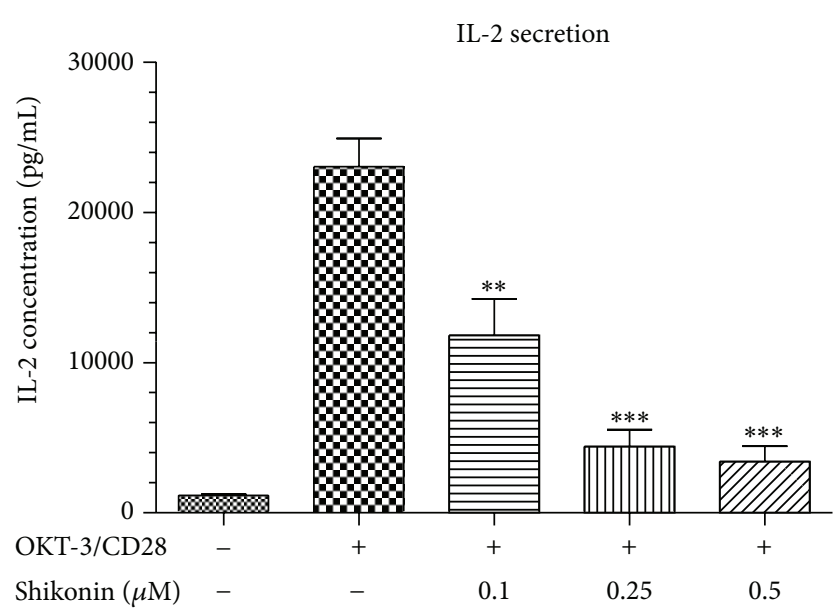

(b)

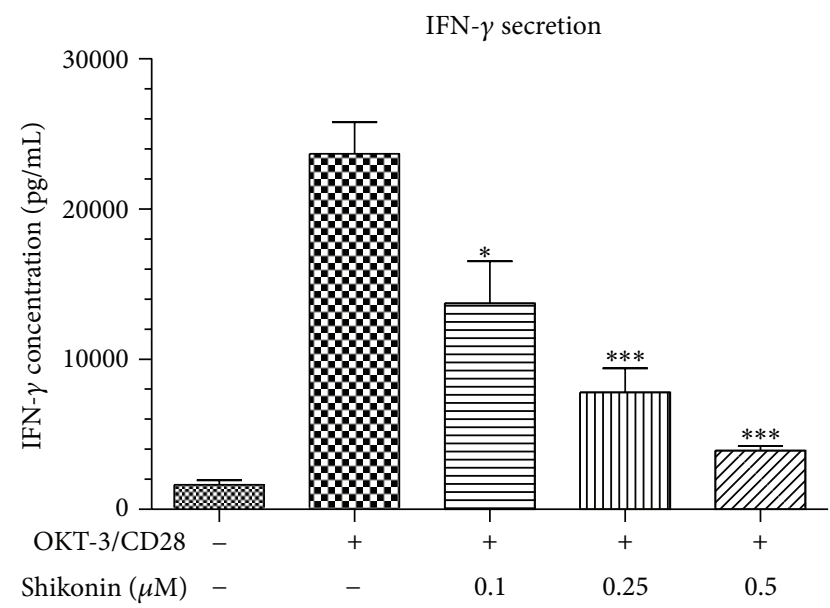

(d)

FIgURE 2: Effect of shikonin on inhibition of IL-2 ( $a$ and b) and IFN- $\gamma$ secretion (c and d) in human T lymphocytes stimulated by $\mathrm{PMA} /$ ionomycin or OKT-3/CD28. The cells $\left(10^{5} /\right.$ well $)$ were firstly treated with shikonin for $2 \mathrm{~h}$ and then stimulated with PMA $(20 \mathrm{ng} / \mathrm{mL}) /$ ionomycin $(1 \mu \mathrm{M})(\mathrm{P} / \mathrm{I})$ or with the coated OKT-3 $(5 \mu \mathrm{g} / \mathrm{mL}) / \mathrm{CD} 28(1 \mu \mathrm{g} / \mathrm{mL})(\mathrm{OKT}-3 / \mathrm{CD} 28)$ for $48 \mathrm{~h}$. The level of IL-2 and IFN$\gamma$ in cell culture supernatants was determined by ELISA method. Data reported represent the mean \pm SEM of three independent experiments. Significance of differences shows as ${ }^{*} P<0.05,{ }^{* *} P<0.01,{ }^{* * *} P<0.001$.

secretion, especially IL-2 and IFN- $\gamma$. To evaluate whether the inhibitory effect of shikonin on human T-cell proliferation was mediated by inhibition of IL-2 and IFN- $\gamma$ secretion, we examined the effect of shikonin on IL-2 and IFN- $\gamma$ secretion. As shown in Figure 2, IL-2 and IFN- $\gamma$ were significantly secreted in the cells evoked by PMA/ionomycin, while this increased secretion could be abolished by treatment of shikonin in a dose-dependent manner.

3.3. Shikonin Arrests Cell Cycle of the Human T Lymphocytes. To further elucidate underlying mechanism of shikonin on suppression of T lymphocyte proliferation, IL-2 and IFN- $\gamma$ secretion, nuclear DNA of the cells was stained by propidium iodide, and then the cell cycle was analyzed by using flow cytometry. As shown in Figure 3, the cells remained largely in the G0/G1 phase in the resting T cells, while after stimulated with PMA/ionomycin, the cells were well activated and progressed through S, G2, and M phases of the cell cycle.
However, when the cells were pretreated with 0.25 or $0.5 \mu \mathrm{M}$ of shikonin, cycling of those cells was blocked in the G0/G1 phase compared to the nonpretreated cells, and the entry of cells into the $\mathrm{S}$ phase of cell cycle was significantly prevented.

3.4. Shikonin Inhibits CD69, CD25, and CD71 Expression on Human T Lymphocytes. The entry of $\mathrm{T}$ cells into the cell cycle and their subsequent progression through G1 phase is accompanied by activation of numerous cellular events including expression of the surface markers of CD69, CD25, and CD71. Our results demonstrated that stimulation with PMA/ionomycin in human T lymphocytes induced expression of CD25, CD69, and CD71 up to $76.0 \%, 52.7 \%$, and $71.6 \%$, respectively, while shikonin produced suppression of CD69 and CD25 expression to $12.0 \%$ and $16.5 \%$. However, shikonin slightly suppressed CD71 expression to 65.6\% Figure 4 .

3.5. Shikonin Inhibits NF- $\kappa B$ Signaling of Human T Lymphocytes. CD25 appears to be regulated at the transcriptional 

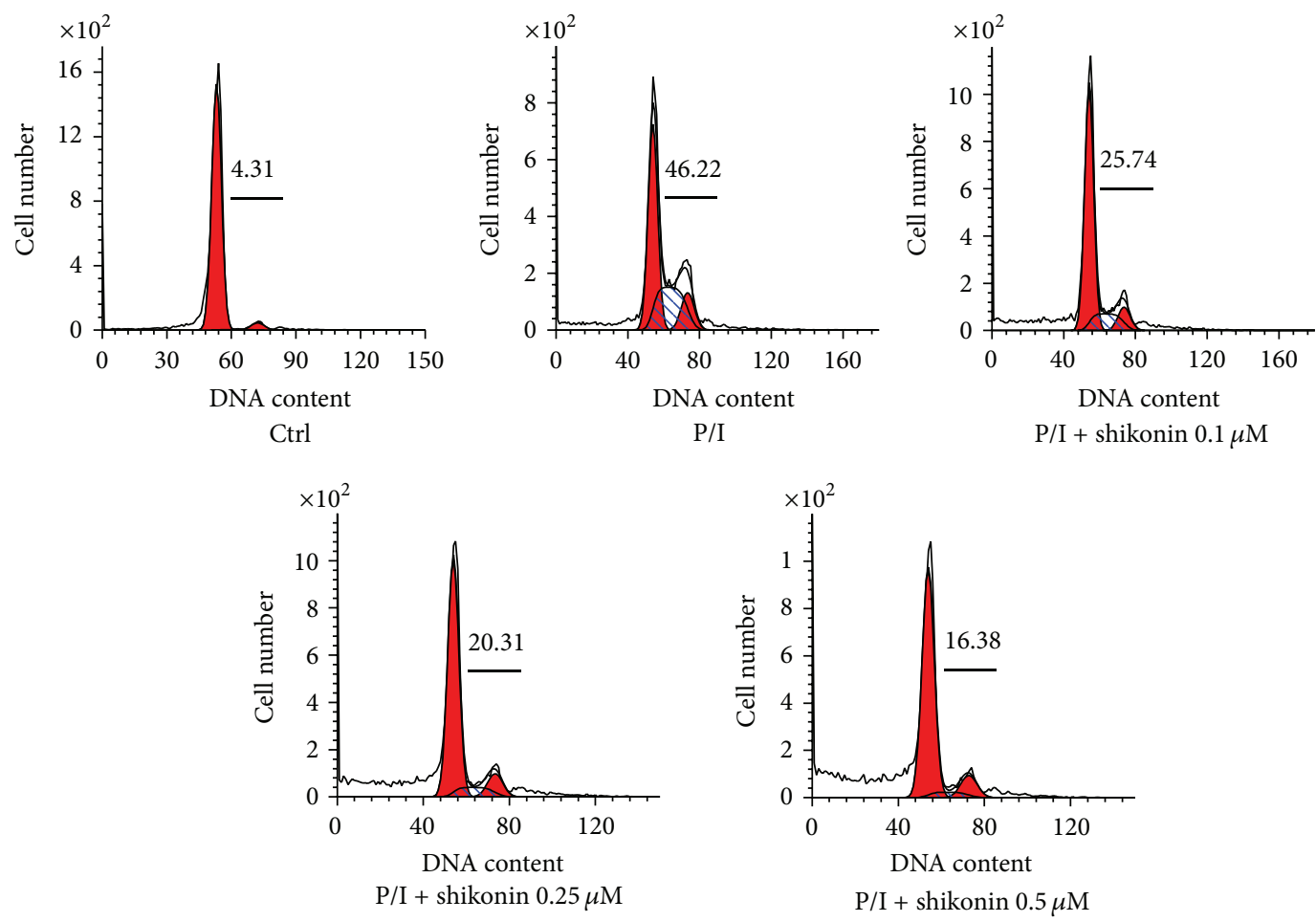

(a)

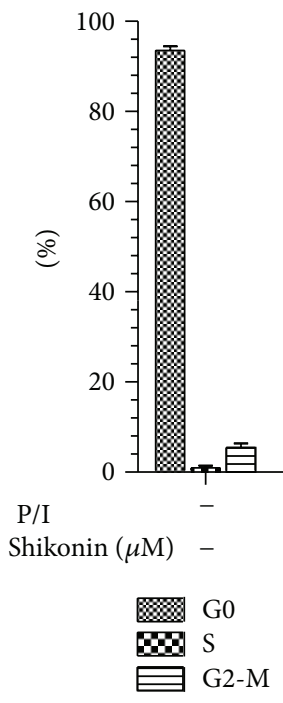

(b)

FIGURE 3: Effect of shikonin on the cell cycle of human T lymphocytes stimulated by PMA/ionomycin. Human T cells $\left(10^{6}\right)$ were pretreated with shikonin for $2 \mathrm{~h}$ then cultured with or without PMA $(20 \mathrm{ng} / \mathrm{mL}) /$ ionomycin $(1 \mu \mathrm{M})(\mathrm{P} / \mathrm{I})$ for $72 \mathrm{~h}$. The cell populations were measured by flow cytometry, and total percentages of the cells entering the $S$ and $\mathrm{G} 2 / \mathrm{M}$ phases of the cell cycle were indicated. Data are a representative experiment out of three independent experiments with similar results.

level by $\mathrm{CD} 28$ through NF- $\kappa \mathrm{B}$ signaling which is mainly regulated by the classical NF- $\kappa \mathrm{B}$ p50-p65 complexes [19], and then we further examined whether expression of NF$\kappa \mathrm{B}$ signaling in the activated human $\mathrm{T}$ lymphocytes could be inhibited by shikonin. The data were analyzed by flow cytometry, and the results indicate that the level of NF$\kappa \mathrm{B}$ nuclear expression in the cells could be significantly elevated by stimulation of PMA/ionomycin. As we expected, the level of NF- $\kappa$ B expression was obviously decreased by treatment of shikonin at $0.5 \mu \mathrm{M}$ (Figure 5(a)). Furthermore, nuclear translocation of $\mathrm{p} 65$ is preceded by phosphorylation and degradation of $\mathrm{I} \kappa \mathrm{B}-\alpha$. To determine whether inhibition of NF- $\kappa$ B activation by shikonin was due to inhibition of $\mathrm{I} \kappa \mathrm{B} \alpha$ degradation, we examined the level of degradation and phosphorylation of $\mathrm{I} \kappa \mathrm{B}-\alpha$ in human $\mathrm{T}$ lymphocytes stimulated by PMA/ionomycin in the absence and presence of 


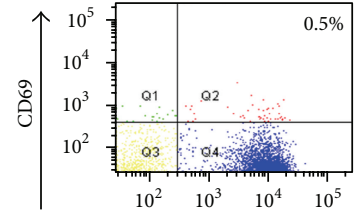

Ctrl

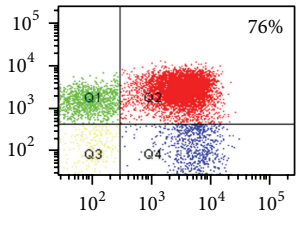

$\mathrm{P} / \mathrm{I}$

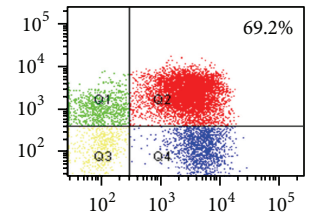

$\mathrm{P} / \mathrm{I}+$ shikonin $0.1 \mu \mathrm{M}$

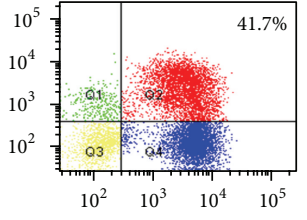

$\mathrm{P} / \mathrm{I}+$ shikonin $0.25 \mu \mathrm{M}$

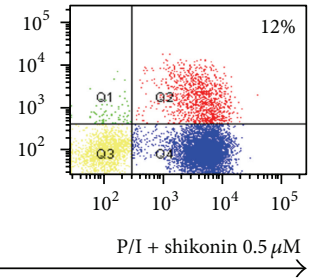

CD3

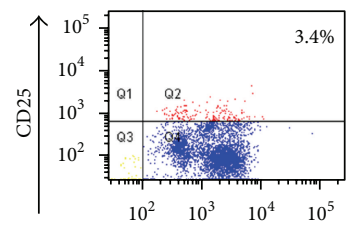

Ctrl

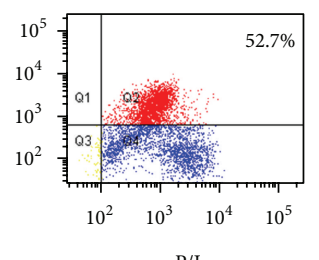

$\mathrm{P} / \mathrm{I}$

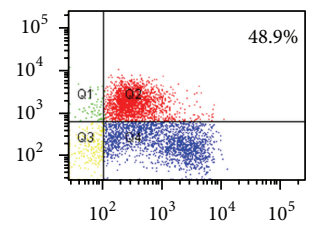

$\mathrm{P} / \mathrm{I}+$ shikonin $0.1 \mu \mathrm{M}$

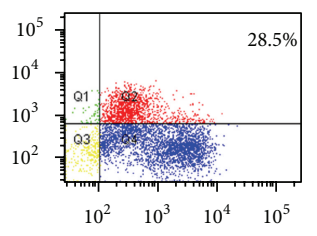

$\mathrm{P} / \mathrm{I}+$ shikonin $0.25 \mu \mathrm{M}$

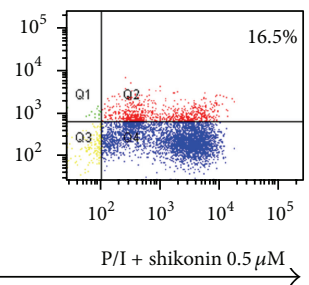

$\mathrm{P} / \mathrm{I}+$ shikonin $0.5 \mu \mathrm{M}$

$\mathrm{CD} 3$

(b)

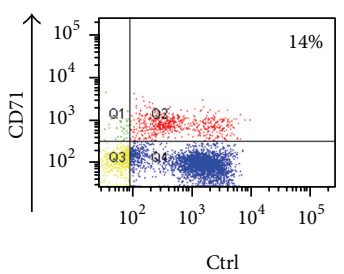

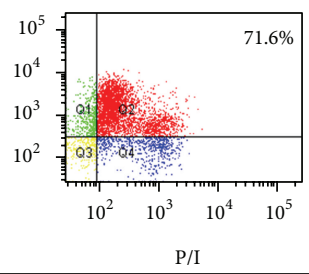

$\mathrm{P} / \mathrm{I}$

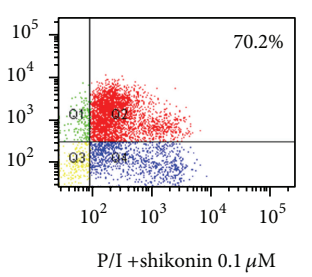

CD3
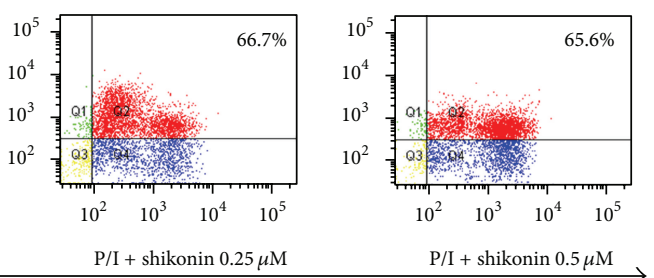

(c)

Figure 4: Effect of shikonin on CD25, CD69, and CD71 expression on human T lymphocytes. Human T lymphocytes $\left(10^{6}\right)$ were pretreated with shikonin for $2 \mathrm{~h}$ and then stimulated by PMA $(20 \mathrm{ng} / \mathrm{mL}) /$ ionomycin $(1 \mu \mathrm{M})(\mathrm{P} / \mathrm{I})$ for $48 \mathrm{~h}$ or $72 \mathrm{~h}$, respectively. The cells were double stained with PE-CD3 and FITC-CD69 (a), PE-CD3 and FITC-CD25 (b), PE-CD3 or FITC-CD71 (c) antibodies and then analyzed by flow cytometry. The unstimulated cells were served as negative control. Values represent percentages of the double stained cells.

shikonin. Tha results showed that PMA/ionomycin induced degradation of $\mathrm{I} \kappa \mathrm{B}-\alpha$, while shikonin markedly suppressed this degradation in a dose-dependent manner (Figure 5(b)). To further determine if the inhibitory effect of shikonin on $\mathrm{I} \kappa \mathrm{B} \alpha$ degradation induced by PMA/ionomycin was associated with inhibition of $\mathrm{I} \kappa \mathrm{B} \alpha$ phosphorylation, we used the proteasome inhibitor $\mathrm{N}$-acetyl-leucyl-leucyl-norleucinal (ALLN) to block degradation of $\mathrm{I} \kappa \mathrm{B} \alpha$ in the experiment, as results showed that $\mathrm{I} \kappa \mathrm{B} \alpha$ phosphorylation was strongly suppressed by shikonin (Figure 5(c)).

3.6. Shikonin Directly Suppresses IKK $\beta$ Activity. IKK is responsible for the phosphorylation and degradation of $\mathrm{I} \kappa \mathrm{B}-$ $\alpha$, while activation of IKK- $\beta$, rather than IKK- $\alpha$, participates in the classical signaling pathway by which the proinflammatory stimuli induce NF- $\kappa \mathrm{B}$ activation through the phosphorylation of $\mathrm{I} \kappa \mathrm{B}-\alpha$. In the current study we found that shikonin significantly inhibited phosphorylation and degradation of $\mathrm{I} \kappa \mathrm{B}-\alpha$ in human lymphocytes, and therefore we further examined if shikonin could directly inhibit the IKK- $\beta$ activity. The results clearly showed that shikonin at $0.25 \mu \mathrm{M}$ and $0.5 \mu \mathrm{M}$ significantly suppressed the activity of
IKK $\beta$ kinase, probably via direct interactions (Figure 6(a)). We further determined whether shikonin could reduce the phosphorylation of IKK $\beta$ induced by PMA/ionomycin. The human $\mathrm{T}$ lymphocytes were pretreated with shikonin and then exposed to PMA/ionomycin for various time periods. Subsequently, the IKK $\alpha / \beta$ phosphorylation in total cell extracts was determined by Western blot analysis. The results shown in Figure 6(b) indicated that PMA/ionomycin induced IKK $\alpha / \beta$ phosphorylation at $120 \mathrm{~min}$, while shikonin concentration significantly prevented phosphorylation of $\mathrm{IKK} \alpha / \beta$ at $0.5 \mu \mathrm{M}$.

3.7. Shikonin Inhibits Phosphorylation of JNK. MAPKs composed of ERK, JNK, and p38 kinase serve as the most ancient signal transductional pathway involving T-cell activation [20] and IL-2 expression [21]. So, we further examined the effect of shikonin on the MAPKs signaling in human T lymphocytes. Total cellular extractions of the cells were prepared, and the signal transduction protein was measured by Western blotting. The results showed that shikonin could obviously suppress JNK phosphorylation but has no influences on ERK and $\mathrm{p} 38$ phosphorylation (Figure 7). 

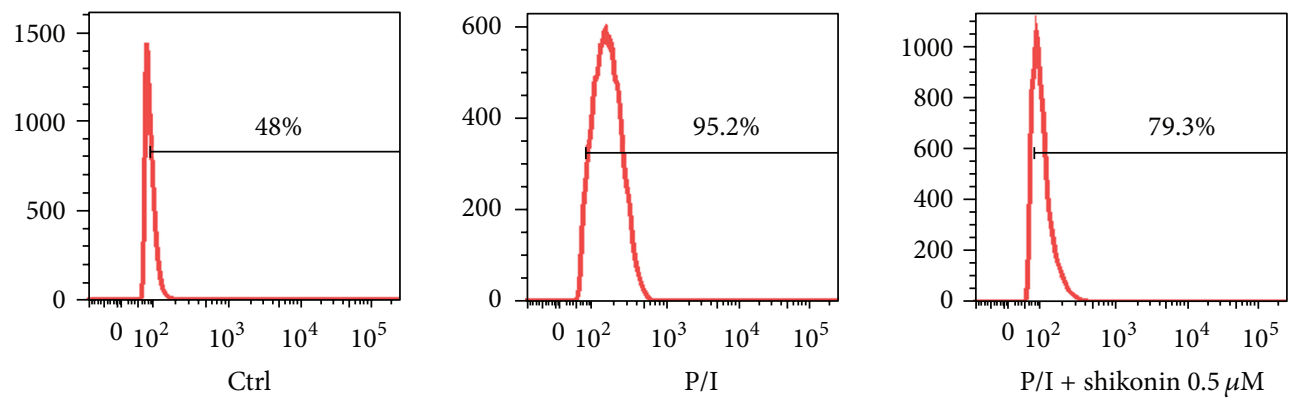

(a)
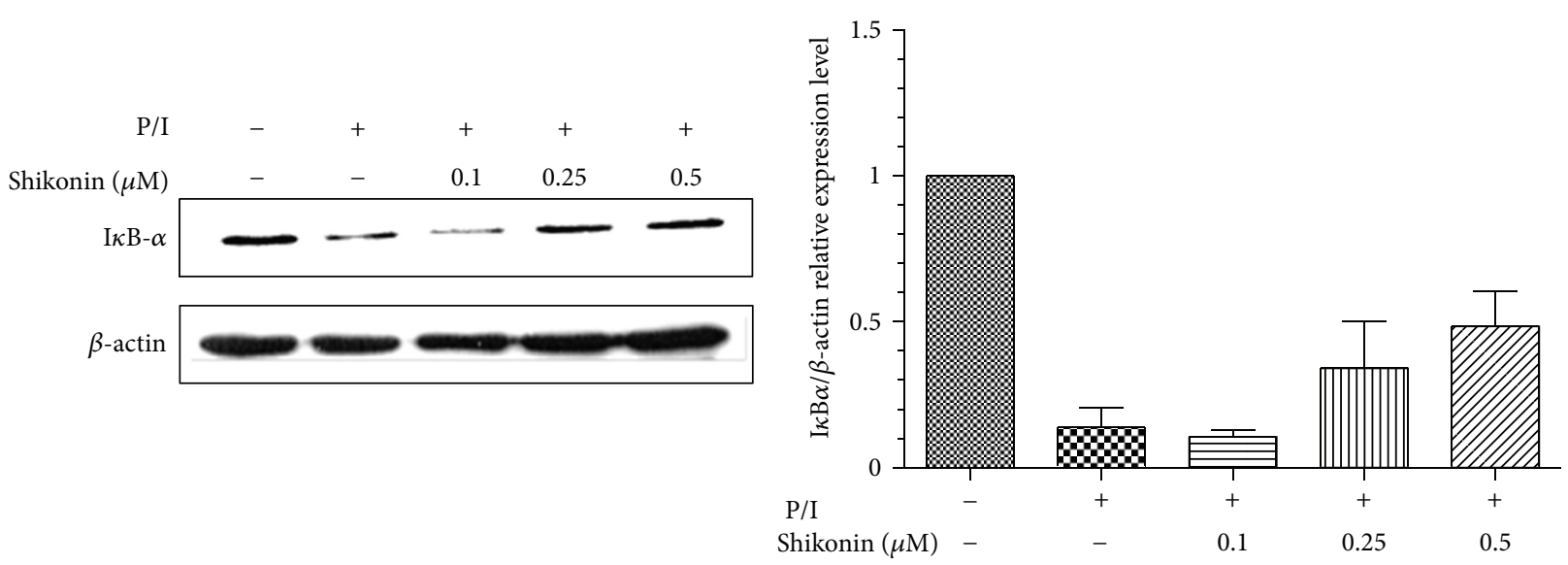

(b)

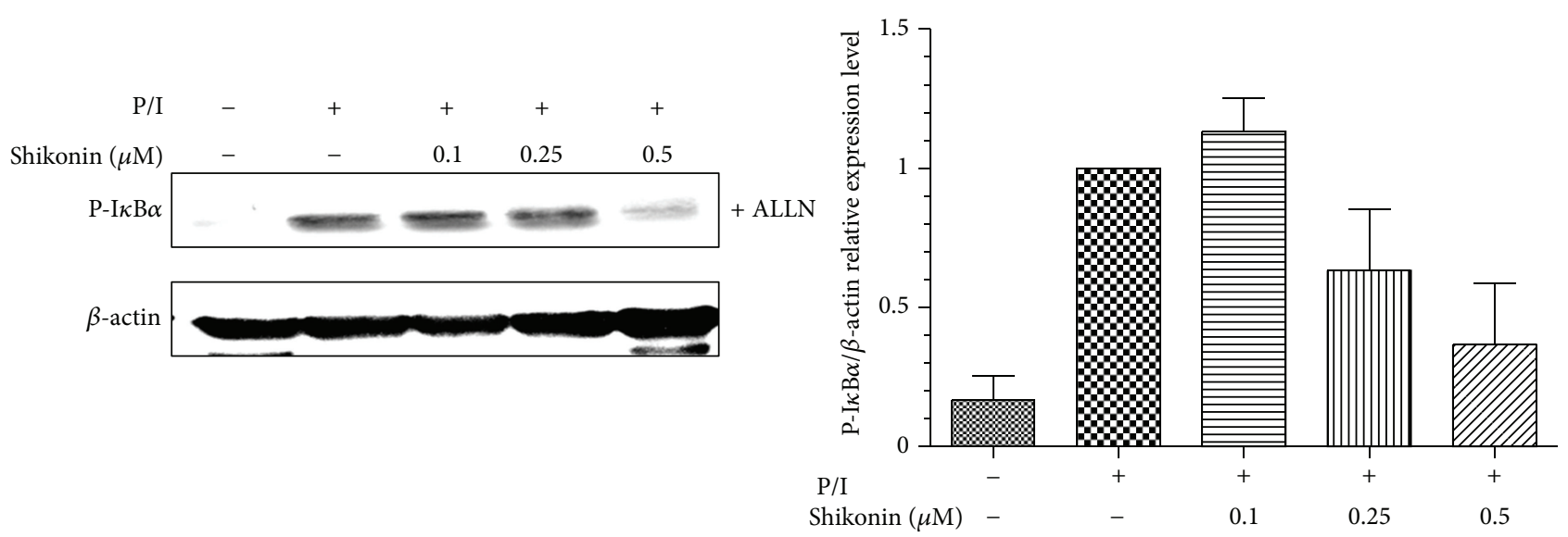

(c)

Figure 5: Effect of shikonin on inhibition of nuclear translocation of NF- $\kappa$ B subunit p65 (a), degradation and phosphorylation of I $\kappa$ B- $\alpha$ in human T lymphocytes stimulated by PMA/ionomycin (b and c). For analysis of the intercellular NF- $\kappa \mathrm{B}$ expression, cells were incubated with shikonin for $60 \mathrm{~min}$, and then fixed immediately by cytofix buffer after costimulation by PMA $(20 \mathrm{ng} / \mathrm{mL}) / \mathrm{ionomycin}(1 \mu \mathrm{M})$ for $120 \mathrm{~min}$, stained with NF- $\kappa \mathrm{B}$ antibody for $60 \mathrm{~min}$ avoiding light, and then analyzed by flow cytometry. The unstimulated cells were served as negative control (a). For detection of $\mathrm{I} \kappa \mathrm{B}-\alpha$, cells were incubated with or without shikonin for $60 \mathrm{~min}$ (b); for detection of pI $\kappa \mathrm{B}-\alpha$, the human T lymphocytes were pretreated with or without shikonin and $100 \mu \mathrm{M}$ ALLN for 60 min (c) and then stimulated with PMA $(20 \mathrm{ng} / \mathrm{mL}) /$ ionomycin $(1 \mu \mathrm{M})(\mathrm{P} / \mathrm{I})$ at $37^{\circ} \mathrm{C}$ for $60 \mathrm{~min}$. The whole-cell lysates were prepared, and the proteins were analyzed by Western blotting using antibodies against $\mathrm{I} \kappa \mathrm{B}-\alpha$ and $\mathrm{P}-\mathrm{I} \kappa \mathrm{B}-\alpha$. Data are representative of three independent experiments.

\section{Discussion}

Previous studies showed that shikonin has diverse pharmacological properties such as antiinflammation and anti-cancer. It could also inhibit the transcriptional activity of cyclooxygenase-2, TNF- $\alpha$ promoters [22], nitric oxide synthase induction, NF- $\kappa \mathrm{B}$ nuclear translocation, as well as the binding of NF- $\kappa$ B to DNA in the RAW264.7 cells, and peritoneal macrophages isolated from Balb/C mice as well [7, 23]. It was reported that shikonin induced apoptosis of macrophages via inhibition of their proteasome as well [24]. Moreover, it has been demonstrated that shikonin effectively suppressed 

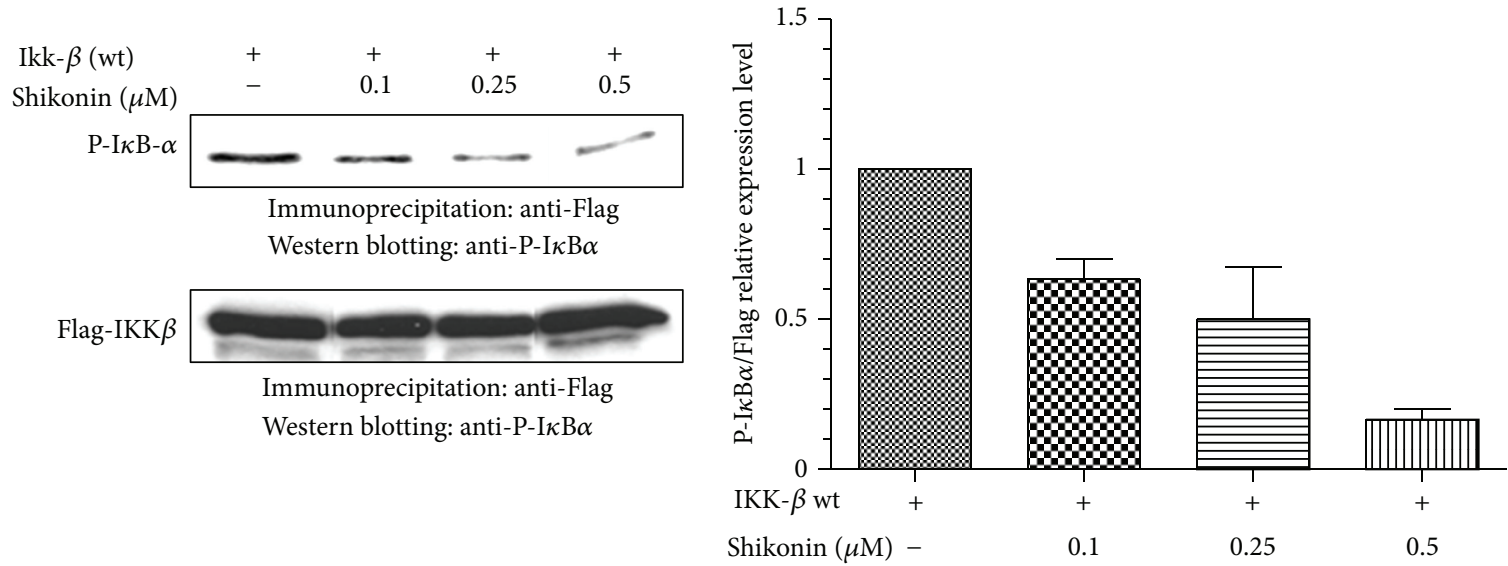

(a)
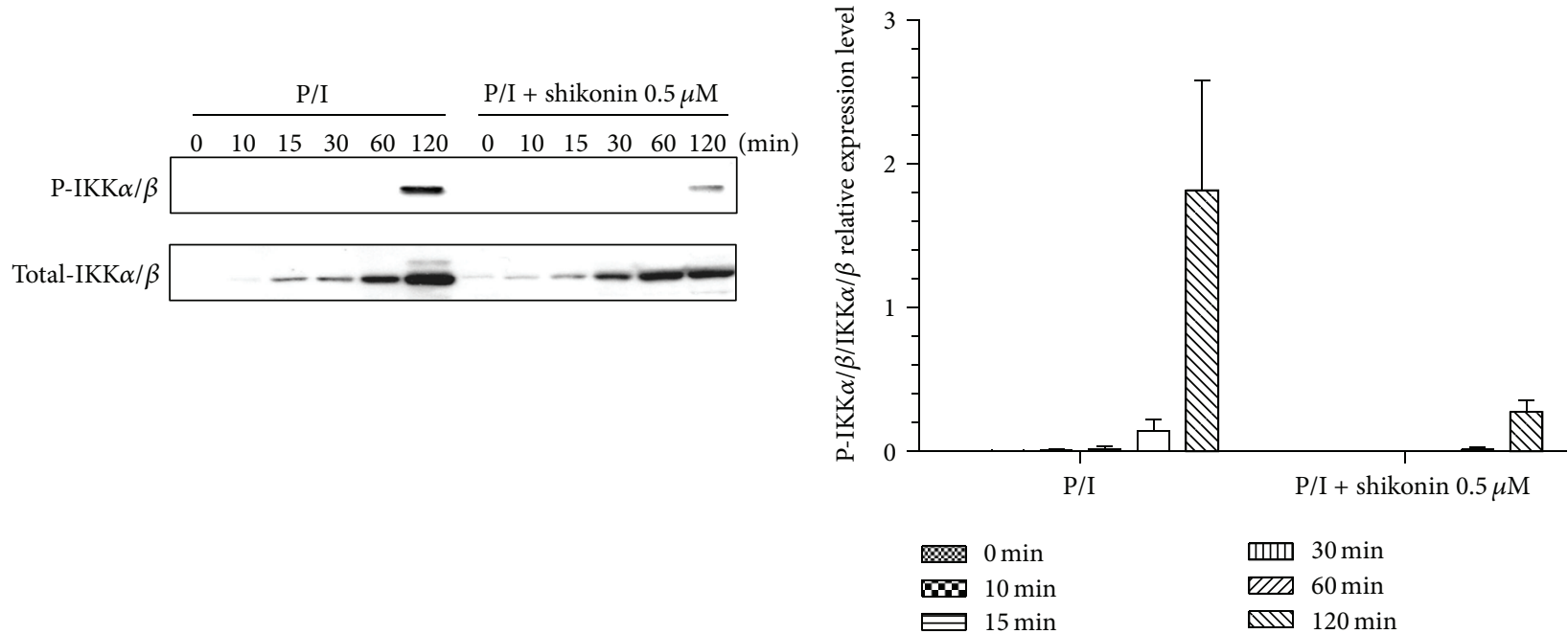

(b)

FIGURE 6: Effect of shikonin on inhibition of IKK- $\beta$ activity (a) and IKK- $\alpha / \beta$ phosphorylation (b). Human HEK293 cells transfected with FLAG-IKK- $\beta$ (wt) plasmid were immunoprecipitated (IP) with anti-Flag antibody, and the IP Flag-IKK- $\beta$ was incubated with GST-I $\kappa$ B $\alpha$ substrate and ATP in the presence or absence of $100 \mu \mathrm{M}$ shikonin. IKK- $\beta$ kinase activity was determined by the level of phosphorylated GST$\mathrm{I} \kappa \mathrm{B} \alpha$ using antibody against $\mathrm{p}-\mathrm{I} \kappa \mathrm{B} \alpha(\mathrm{a})$. The human T lymphocytes were pretreated with shikonin at $37^{\circ} \mathrm{C}$ for 60 min and then stimulated with PMA $(20 \mathrm{ng} / \mathrm{mL}) /$ ionomycin $(1 \mu \mathrm{M})(\mathrm{P} / \mathrm{I})$ at $37^{\circ} \mathrm{C}$ for different time points. The whole-cell lysates were prepared, and proteins were analyzed by Western blotting using antibodies against IKK $\alpha / \beta$ and the phosphorylated form of IKK $\alpha / \beta$. Data are representative of three independent experiments.

maturation of bone marrow-derived dendritic cells (BMDC) induced by ovalbumin (OVA) and thymic stromal lymphopoietin (TSLP) in vitro [2]. We found that investigation of anti-inflammatory effect of shikonin mainly focused on the macrophage. Physiologically, T cell is another dominant cell population for mediating immune and inflammatory responses in humans and plays the key role in the secretion of cytokines as well as induction of inflammatory diseases; however, there is no report regarding the action of shikonin or its derivatives on $\mathrm{T}$ cells. In the current study, it is the first time to demonstrate the inhibitory property of shikonin on human T lymphocytes, namely, significant suppressions on the T-cell proliferation, IL-2 and IFN- $\gamma$ secretion, cell cycle arrest and cell surface marker activation, through inhibition on NF- $\kappa$ B signaling, and JNK phosphorylation via direct abrogate IKK $\beta$ activity.
Activation and clonal expansion of $\mathrm{T}$ cells is the central event in the generation of immune and inflammatory responses. Productive T-cell activation depends on the essential signal (signal 1) provided by peptide/MHC complex and additional signal (signal 2) provided by CD28 [25]. Costimulation of $\mathrm{CD} 28$ and the immobilized anti-CD3 antibody can dramatically augment $\mathrm{T}$-cell responses showing proliferation and cytokine secretion [26]. Moreover, PMA, one of phorbol esters and diacyl glycerol analogs, could stimulate PKC $\theta$ activity, while ionomycin, one of calcium ionophores, results in an increase at the intracellular calcium level due to the higher extracellular calcium concentration. PMA/ionomycin can lead to T-cell activation through bypass surface TCR engagement and cross-linking requirements and directly activates intracellular signaling pathways [27]. Thus, in our current studies both OKT-3/CD28 and 

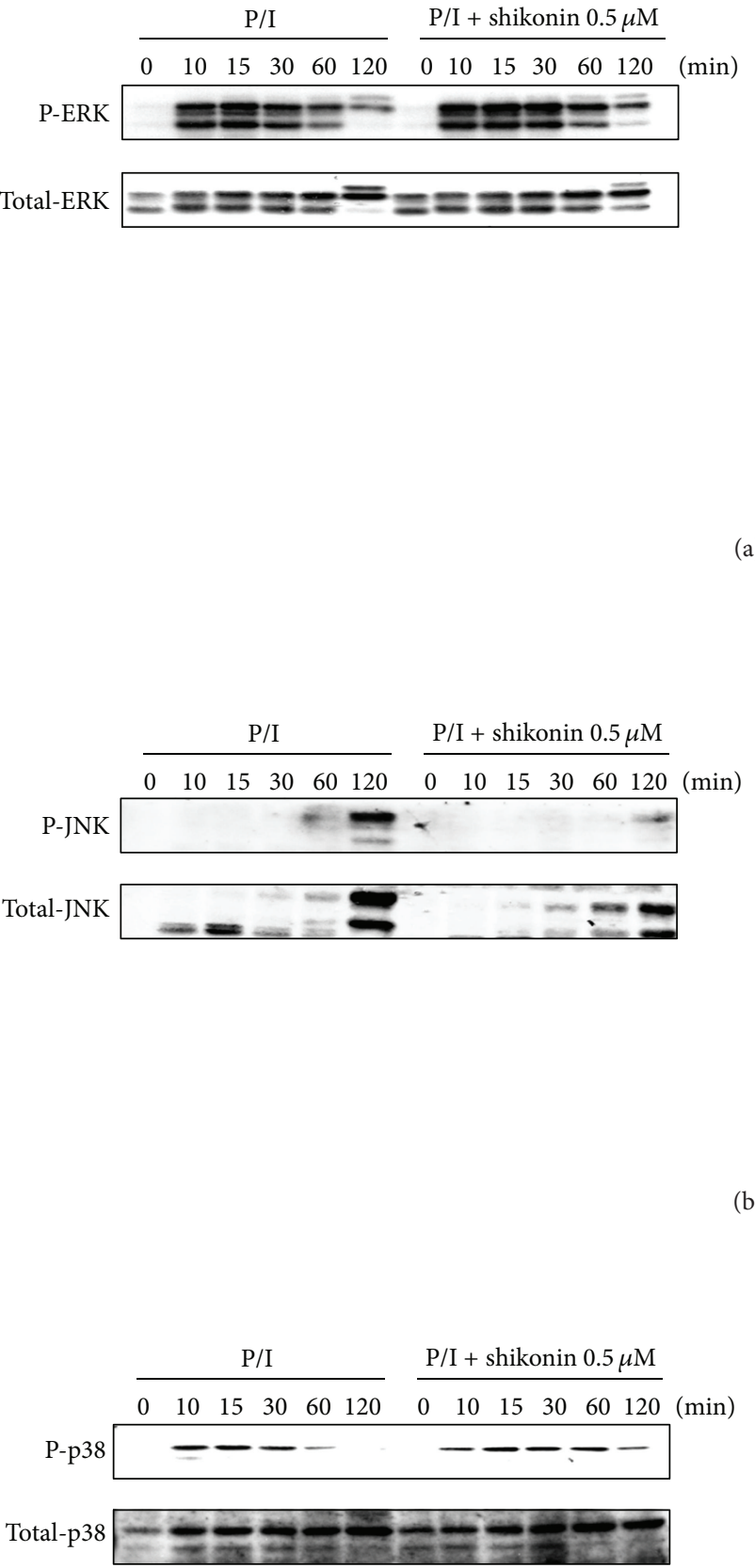

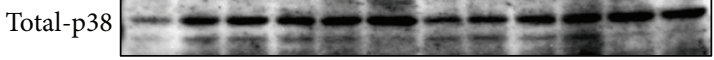
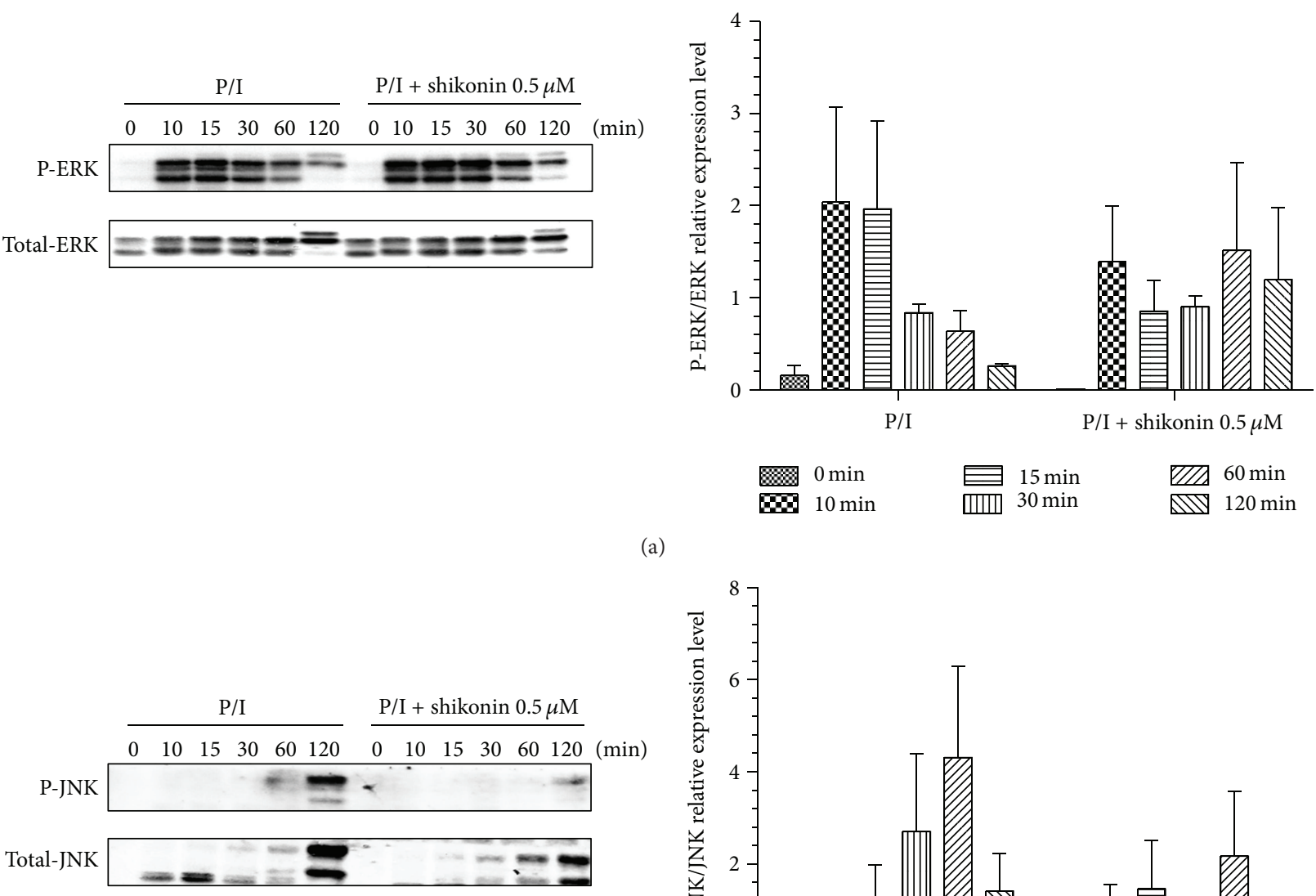

(a)

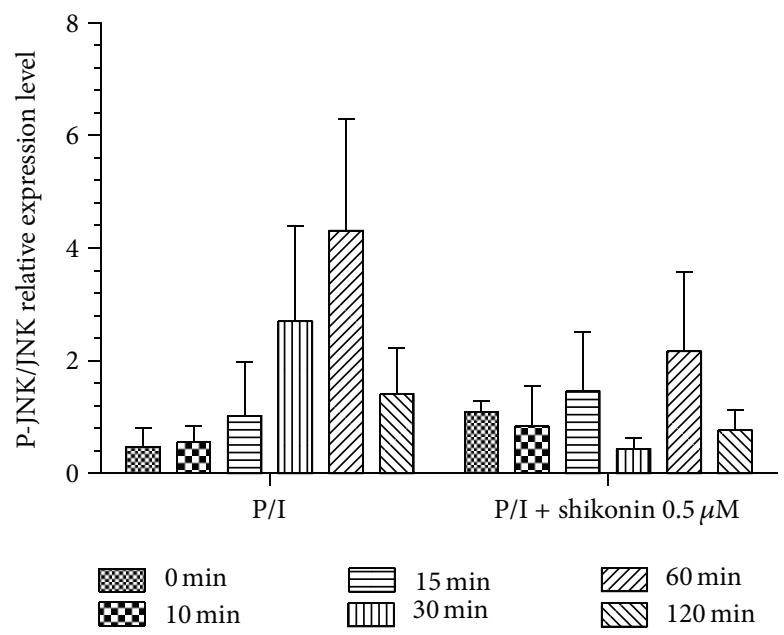

(b)

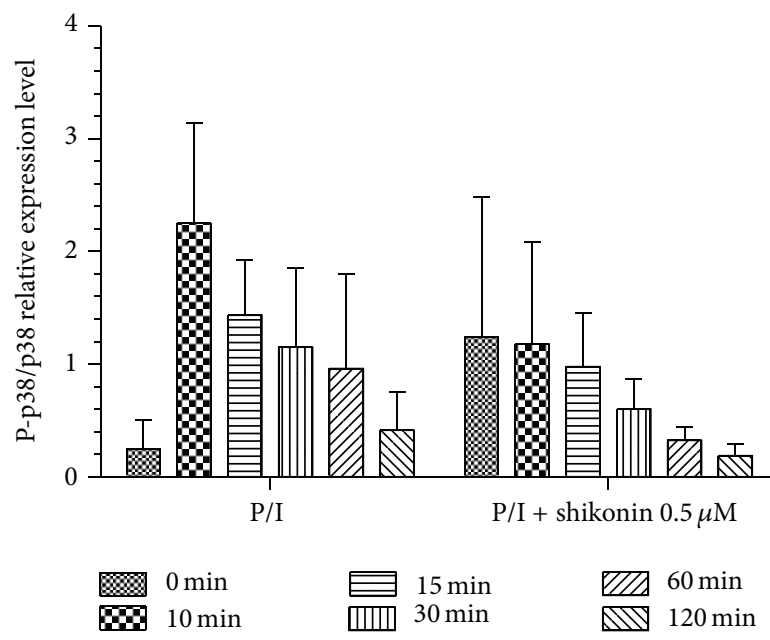

(c)

FIGURE 7: Effect of shikonin on MAPK phosphorylation stimulated by PMA/ionomycin. The human T lymphocytes were pretreated with shikonin at $37^{\circ} \mathrm{C}$ for $60 \mathrm{~min}$ and then costimulated with PMA $(20 \mathrm{ng} / \mathrm{mL}) /$ ionomycin $(1 \mu \mathrm{M})(\mathrm{P} / \mathrm{I})$ at $37^{\circ} \mathrm{C}$ for different time points. The wholecell lysates were prepared, and proteins were analyzed by Western blotting using antibodies against ERK, JNK, and p38 and the phosphorylated forms of ERK, JNK, and p38 (a, b, and c). Data are representative of three independent experiments. 
PMA/ionomycin were employed to elicit T-cell activation responses, which may fit to the immune and inflammatory responses in clinic as well as the translational research for developing a candidate anti-inflammatory drug. We found that shikonin significantly inhibited $\mathrm{T}$ cell proliferation, IL-2 and IFN- $\gamma$ secretion induced by either PMA/ionomycin or OKT-3/CD28, indicating that shikonin may have a potency of inhibiting PKC $\theta$ or its downstream. After being calculated, we found that shikonin inhibited T-cell proliferation with $\mathrm{IC}_{50}$ values of $2.4 \mu \mathrm{g} / \mathrm{mL}$. Although the concentration is relatively higher than cyclosporine $\mathrm{A}\left(\mathrm{IC}_{50}=10 \mathrm{ng} / \mathrm{mL}\right)$ [28], a classical immunosuppressive drug, the immune-suppressive effect of shikonin on T-cell proliferation is better than other compounds derived from plant medicine, such as Suberosin and Pseudolaric acid B, of which effective concentration is $100 \mu \mathrm{M}$ and $10 \mu \mathrm{M}$, respectively $[29,30]$.

IL-2 transcription and secretion promote T-cell cycle progression and effector functions in the activated T cells [31]; hence, we further investigated the effect of shikonin on the cell cycle. Resting T cells are mainly arrested in G0 phase, while the cells can enter into the cell cycle to proliferate when they are challenged by antigen or mitogen [18, 32]. In the present study, we found that shikonin treatment could prevent cells from entering the phases of cell cycle, implying that shikonin-mediated cell cycle arrest might further contribute to the inhibition of T-cell proliferation, production of the growth factors of T cells including IL-2 and IFN- $\gamma$ secretion $[33,34]$. As there was no cytotoxicity of shikonin on human $\mathrm{T}$ lymphocytes at $0.5 \mu \mathrm{M}$, it can be concluded that the immunosuppressive effect of shikonin on human $\mathrm{T}$ lymphocytes is resulted from its pharmacological inhibitory property.

To further elucidate the underlying molecular mechanisms of shikonin on T-cell activation, we further investigated its action on T-cell activation markers, including CD25 (IL$2 \alpha$ receptor), CD69, and CD71 [35]. CD25 can mediate full expression of immune responses through interacting with IL-2 and its receptors, triggering cellular proliferation, and culminating in the emergence of effector $\mathrm{T}$ cells [36]. In general, CD25 is regulated by CD28 at transcriptional level through NF- $\kappa$ B signaling and highly expressed during Tcell activation [37-39]. Meanwhile CD69 is the earliest T-cell activation, while CD71 is the latest $\mathrm{T}$ cell activation marker [40]. All of these markers participate in T-cell proliferation, and levels of these markers correlate with the degree of immune responses. Results in the current study showed that shikonin could significantly suppress CD25 and CD69 expression but slightly influence CD71 expression. Considering the close correlations between CD25 expression and NF$\kappa \mathrm{B}$ signaling we further proposed that shikonin might inhibit T-cell activation by blocking NF- $\kappa \mathrm{B}$ signaling. Moreover, NF- $\kappa \mathrm{B}$ regulates IL-2 production and T-cell proliferation. Consequently, we further performed experiments to clarify the effect of shikonin on NF- $\kappa$ B signaling pathway.

The constitutive activation of NF- $\kappa \mathrm{B}$ signaling is often associated with inflammatory and autoimmune conditions [41]. Recently the strategies of regulation or inhibition of NF$\kappa \mathrm{B}$ signaling has been deeply investigated for drug discovery, such as suppression of $26 \mathrm{~S}$ proteasome and interfere with the binding of NF- $\kappa \mathrm{B}$ to DNA. Inhibition on $26 \mathrm{~S}$ proteasome has been evident of one of the attractive targets for suppressing NF- $\kappa \mathrm{B}$ activation, as it could inhibit $\mathrm{I} \kappa \mathrm{B} \alpha$ phosphorylation and degradation, and NF- $\kappa \mathrm{B}$ nuclear translocation as well. However, the proteasome is involved in the degradation of all polyubiquitinated proteins; thus it is difficult to find the most specific inhibitors on the enzymes like E3 ubiquitin ligases and E3 ubiquitin-conjugating enzymes, which are responsible for the phosphorylation-dependent polyubiquitination of I $\kappa$ Bs [13]. Considering those complexities above, searching for the inhibitors on the IKK activity may offer the most effective and selective strategy for suppression of NF- $\kappa \mathrm{B}$ activation [13]. Our present data demonstrated that shikonin could significantly suppress NF- $\kappa \mathrm{B}$ signaling pathway through direct suppression of the IKK $\beta$ activity, indicating prevention of the NF- $\kappa \mathrm{B}$ nuclear translocation, and $\mathrm{I} \kappa \mathrm{B} \alpha$ phosphorylation and degradation, IKK $\alpha / \beta$ phosphorylation.

MAPK cascades play important role in regulating IL-2 expression [21], and inhibition of ERK or p38 phosphorylation has been proven to prevent IL-2 expression [42, 43], which indicates that both of them are essential for T-cell activation. Moreover, JNK could phosphorylate c-jun, a member of the AP-1 transcriptional factor family which can generate T-cell activation and is involved in gene transcriptional activity of IL-2 $[44,45]$. Thus, we investigated the effect of shikonin on MAPK signaling, and the data showed that shikonin inhibited JNK phosphorylation without influence on the phosphorylation of ERK and p38. JNK pathway seems to play multiple roles in T-cell immune responses, as it can be activated in $\mathrm{T}$ cells by stimulation, modulation of cytokine secretion, and cell proliferation $[46,47]$. Taken together, the inhibitory effect of shikonin on human $\mathrm{T}$ lymphocytes may mainly result from suppression of IKK $\beta$ activity in the cells.

\section{Conclusion}

In summary, the current studies have firstly demonstrated immunosuppressive effect of shikonin on human T lymphocytes through suppression of cell activation, while the major molecular mechanisms are involved in inhibition of CD25, CD69 expression, cell cycle, NF- $\kappa \mathrm{B}$ and JNK signaling, and IKK $\beta$ activity. Based on the suppressive effect of shikonin on human T cells, shikonin may have significant potentials to be investigated as a lead compound for the design and development of a new immunosuppressant for preventing graft rejection and treating autoimmune diseases.

\section{Conflict of Interests}

The authors declare that they have no conflict of interests.

\section{Acknowledgment}

This work is supported by Macau Science and Technology Development Fund (065/2011/A3). 


\section{References}

[1] X. Chen, L. Yang, J. J. Oppenheim, and O. M. Zack Howard, "Cellular pharmacology studies of shikonin derivatives," Phytotherapy Research, vol. 16, no. 3, pp. 199-209, 2002.

[2] C. C. Lee, C. N. Wang, Y. T. Lai et al., "Shikonin inhibits maturation of bone marrow-derived dendritic cells and suppresses allergic airway inflammation in a murine model of asthma," British Journal of Pharmacology, vol. 161, no. 7, pp. 1496-1511, 2010.

[3] Z. Wu, L. Wu, L. Li, S. I. Tashiro, S. Onodera, and T. Ikejima, "p53-mediated cell cycle arrest and apoptosis induced by shikonin via a caspase-9-dependent mechanism in human malignant melanoma A375-S2 cells," Journal of Pharmacological Sciences, vol. 94, no. 2, pp. 166-176, 2004.

[4] J. P. Wang, S. L. Raung, L. C. Chang, and S. C. Kuo, "Inhibition of hind-paw edema and cutaneous vascular plasma extravasation in mice by acetylshikonin," European Journal of Pharmacology, vol. 272, no. 1, pp. 87-95, 1995.

[5] X. Mao, C. Rong Yu, W. Hua Li, and W. Xin Li, "Induction of apoptosis by shikonin through a ROS/JNK-mediated process in Bcr/Abl-positive chronic myelogenous leukemia (CML) cells," Cell Research, vol. 18, no. 8, pp. 879-888, 2008.

[6] Y. W. Cheng, C. Y. Chang, K. L. Lin, C. M. Hu, C. H. Lin, and J. J. Kang, "Shikonin derivatives inhibited LPS-induced NOS in RAW 264.7 cells via downregulation of MAPK/NF- $\kappa$ B signaling," Journal of Ethnopharmacology, vol. 120, no. 2, pp. 264-271, 2008.

[7] I. Andújar, M. C. Recio, T. Bacelli, R. M. Giner, and J. L. Ríos, "Shikonin reduces oedema induced by phorbol ester by interfering with $\mathrm{I} \kappa \mathrm{B} \alpha$ degradation thus inhibiting translocation of NF- $\kappa$ B to the nucleus," British Journal of Pharmacology, vol. 160, no. 2, pp. 376-388, 2010.

[8] S. C. Chiu, S. W. Tsao, P. I. Hwang, S. Vanisree, Y. A. Chen, and N. S. Yang, "Differential functional genomic effects of antiinflammatory phytocompounds on immune signaling," $B M C$ Genomics, vol. 11, no. 1, article 513, 2010.

[9] E. Dale, M. Davis, and D. L. Faustman, "A role for transcription factor NF- $\kappa \mathrm{B}$ in autoimmunity: possible interactions of genes, sex, and the immune response," American Journal of Physiology, vol. 30, no. 4, pp. 152-158, 2006.

[10] M. S. Hayden, A. P. West, and S. Ghosh, "NF- $\kappa$ B and the immune response," Oncogene, vol. 25, no. 51, pp. 6758-6780, 2006.

[11] Y. Yamamoto and R. B. Gaynor, "Therapeutic potential of inhibition of the NF- $\kappa$ B pathway in the treatment of inflammation and cancer," Journal of Clinical Investigation, vol. 107, no. 2, pp. 135-142, 2001.

[12] A. C. Bharti and B. B. Aggarwal, "Nuclear factor-kappa B and cancer: its role in prevention and therapy," Biochemical Pharmacology, vol. 64, no. 5-6, pp. 883-888, 2002.

[13] M. Karin, Y. Yamamoto, and Q. M. Wang, "The IKK NF- $\kappa$ B system: a treasure trove for drug development," Nature Reviews Drug Discovery, vol. 3, no. 1, pp. 17-26, 2004.

[14] J. M. Kyriakis and J. Avruch, "Mammalian mitogen-activated protein kinase signal transduction pathways activated by stress and inflammation," Physiological Reviews, vol. 81, no. 2, pp. 807869, 2001.

[15] R. Ghittoni, L. Patrussi, K. Pirozzi et al., "Simvastatin inhibits T-cell activation by selectively impairing the function of Ras superfamily GTPases," FASEB Journal, vol. 19, no. 6, pp. 605607, 2005.
[16] D. Gerlier and N. Thomasset, "Use of MTT colorimetric assay to measure cell activation," Journal of Immunological Methods, vol. 94, no. 1-2, pp. 57-63, 1986.

[17] C. Y. Leung, L. Liu, R. N. S. Wong, Y. Y. Zeng, M. Li, and H. Zhou, "Saikosaponin-d inhibits $\mathrm{T}$ cell activation through the modulation of PKC $\theta$, JNK, and NF- $\kappa \mathrm{B}$ transcription factor," Biochemical and Biophysical Research Communications, vol. 338, no. 4, pp. 1920-1927, 2005.

[18] R. Sancho, A. Macho, L. De La Vega et al., "Immunosuppressive activity of endovanilloids: $\mathrm{N}$-arachidonoyl-dopamine inhibits activation of the NF- $\kappa \mathrm{B}, \mathrm{NFAT}$, and activator protein 1 signaling pathways," Journal of Immunology, vol. 172, no. 4, pp. 2341-2351, 2004.

[19] L. P. Kane, J. Lin, and A. Weiss, "It's all Rel-ative: NF- $\kappa$ B and CD28 costimulation of T-cell activation," Trends in Immunology, vol. 23, no. 8, pp. 413-420, 2002.

[20] T. Yoshizawa, D. Hammaker, S. E. Sweeney, D. L. Boyle, and G. S. Firestein, "Synoviocyte innate immune responses-I. Differential regulation of interferon responses and the JNK pathway by MAPK kinases," Journal of Immunology, vol. 181, no. 5, pp. 3252-3258, 2008.

[21] C. Dong, R. J. Davis, and R. A. Flavell, "MAP kinases in the immune response," Annual Review of Immunology, vol. 20, pp. 55-72, 2002.

[22] S. C. Chiu and N. S. Yang, "Inhibition of tumor necrosis factor- $\alpha$ through selective blockade of Pre-mRNA splicing by shikonin," Molecular Pharmacology, vol. 71, no. 6, pp. 1640-1645, 2007.

[23] I. Andújar, J. L. Ríos, R. M. Giner, J. Miguel Cerdá, and M. del Carmen Recio, "Beneficial effect of shikonin on experimental colitis induced by dextran sulfate sodium in BALB/c mice," Evidence-Based Complementary and Alternative Medicine, vol. 2012, Article ID 271606, 15 pages, 2012.

[24] L. Lu, A. Qin, H. Huang et al., "Shikonin extracted from medicinal Chinese herbs exerts anti-inflammatory effect via proteasome inhibition," European Journal of Pharmacology, vol. 658, no. 2-3, pp. 242-247, 2011.

[25] M. L. Alegre, K. A. Frauwirth, and C. B. Thompson, "T-cell regulation by CD28 and CTLA-4," Nature Reviews Immunology, vol. 1, no. 3, pp. 220-228, 2001.

[26] B. B. Hashemi, J. E. Penkala, C. Vens, H. Huls, M. Cubbage, and C. F. Sams, "T cell activation responses are differentially regulated during clinorotation and in spaceflight," FASEB Journal, vol. 13, no. 14, pp. 2071-2082, 1999.

[27] N. Isakov and A. Altman, "PKC-theta-mediated signal delivery from the TCR/CD28 surface receptors," Frontiers in Immunology, vol. 3, article 273, 2012.

[28] S. P. Umland, H. Shah, J. P. Jakway et al., "Effects of cyclosporin $\mathrm{A}$ and dinactin on T-cell proliferation, interleukin-5 production, and murine pulmonary inflammation," American Journal of Respiratory Cell and Molecular Biology, vol. 20, no. 3, pp. 481492, 1999.

[29] T. Li, V. K. W. Wong, Q. Y. Xiao, F. W. Yuen, H. Zhou, and L. Liu, "Pseudolaric acid B suppresses T lymphocyte activation through inhibition of NF- $\kappa \mathrm{B}$ signaling pathway and $\mathrm{p} 38$ phosphorylation," Journal of Cellular Biochemistry, vol. 108, no. 1, pp. 87-95, 2009.

[30] Y. C. Chen, W. J. Tsai, M. H. Wu, L. C. Lin, and Y. C. Kuo, "Suberosin inhibits proliferation of human peripheral blood mononuclear cells through the modulation of the transcription factors NF-AT and NF- $\kappa$ B," British Journal of Pharmacology, vol. 150, no. 3, pp. 298-312, 2007. 
[31] X. Wang, J. Hao, D. L. Metzger et al., "B7-H4 treatment of T cells inhibits ERK, JNK, p38, and AKT activation,” PLoS ONE, vol. 7, Article ID e28232, 2012.

[32] Y. C. Kuo, S. C. Weng, C. J. Chou, T. T. Chang, and W. J. Tsai, "Activation and proliferation signals in primary human T lymphocytes inhibited by ergosterol peroxide isolated from Cordyceps cicadae," British Journal of Pharmacology, vol. 140, no. 5, pp. 895-906, 2003.

[33] H. O. Pae, G. S. Oh, B. M. Choi et al., "Carbon Monoxide Produced by Heme Oxygenase-1 Suppresses T Cell Proliferation via Inhibition of IL-2 Production," Journal of Immunology, vol. 172, no. 8, pp. 4744-4751, 2004.

[34] M. F. Krummel and J. P. Allison, "CTLA-4 engagement inhibits IL-2 accumulation and cell cycle progression upon activation of resting T cells," Journal of Experimental Medicine, vol. 183, no. 6, pp. 2533-2540, 1996.

[35] S. Samarasinghe, C. Mancao, M. Pule et al., "Functional characterization of alloreactive T cells identifies CD25 and CD71 as optimal targets for a clinically applicable allodepletion strategy," Blood, vol. 115, no. 2, pp. 396-407, 2010.

[36] K. H. Chao, M. Y. Wu, J. H. Yang, S. U. Chen, Y. S. Yang, and H. N. Ho, "Expression of the interleukin-2 receptor $\alpha(\mathrm{CD} 25)$ is selectively decreased on decidual $\mathrm{CD}^{+}$and $\mathrm{CD} 8^{+} \mathrm{T}$ lymphocytes in normal pregnancies," Molecular Human Reproduction, vol. 8, no. 7, pp. 667-673, 2002.

[37] H. P. Kim, J. Imbert, and W. J. Leonard, "Both integrated and differential regulation of components of the IL-2/IL-2 receptor system," Cytokine and Growth Factor Reviews, vol. 17, no. 5, pp. 349-366, 2006.

[38] J. X. Lin and W. J. Leonard, "Signaling from the IL-2 receptor to the nucleus," Cytokine and Growth Factor Reviews, vol. 8, no. 4, pp. 313-332, 1997.

[39] J. F. Camargo, M. P. Quinones, S. Mummidi et al., "CCR5 expression levels influence NFAT translocation, IL-2 production, and subsequent signaling events during T lymphocyte activation," Journal of Immunology, vol. 182, no. 1, pp. 171-182, 2009.

[40] A. Caruso, S. Licenziati, M. Corulli et al., "Flow cytometric analysis of activation markers on stimulated $\mathrm{T}$ cells and their correlation with cell proliferation," Cytometry, vol. 27, pp. 71-76, 1997.

[41] P. P. Tak and G. S. Firestein, "NF- $\kappa$ B: a key role in inflammatory diseases," Journal of Clinical Investigation, vol. 107, no. 1, pp. 7-11, 2001.

[42] T. Koike, H. Yamagishi, Y. Hatanaka et al., "A novel ERKdependent signaling process that regulates interleukin-2 expression in a late phase of $\mathrm{T}$ cell activation," Journal of Biological Chemistry, vol. 278, no. 18, pp. 15685-15692, 2003.

[43] J. Zhang, K. V. Salojin, J. X. Gao, M. J. Cameron, I. Bergerot, and T. L. Delovitch, "p38 Mitogen-activated protein kinase mediates signal integration of TCR/CD28 costimulation in primary murine T cells," Journal of Immunology, vol. 162, no. 7, pp. 38193829, 1999.

[44] M. Li-Weber, M. K. Treiber, M. Giaisi et al., "Ultraviolet irradiation suppresses $\mathrm{T}$ cell activation via blocking TCR-mediated ERK and NF- $\kappa$ B signaling pathways," Journal of Immunology, vol. 175, no. 4, pp. 2132-2143, 2005.

[45] V. K. W. Wong, H. Zhou, S. S. F. Cheung, T. Li, and L. Liu, "Mechanistic study of saikosaponin-d (Ssd) on suppression of murine T lymphocyte activation," Journal of Cellular Biochemistry, vol. 107, no. 2, pp. 303-315, 2009.
[46] C. Dong, D. D. Yang, C. Tournler et al., "JNK is required for effector T-cell function but not for T-cell activation," Nature, vol. 405, no. 6782, pp. 91-94, 2000.

[47] A. M. Manning and R. J. Davis, "Targeting JNK for therapeutic benefit: from junk to gold?” Nature Reviews Drug Discovery, vol. 2, no. 7, pp. 554-565, 2003. 


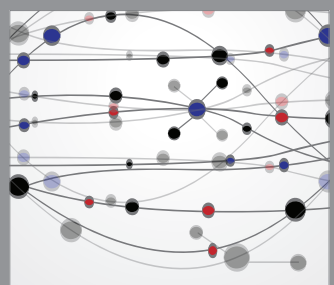

The Scientific World Journal
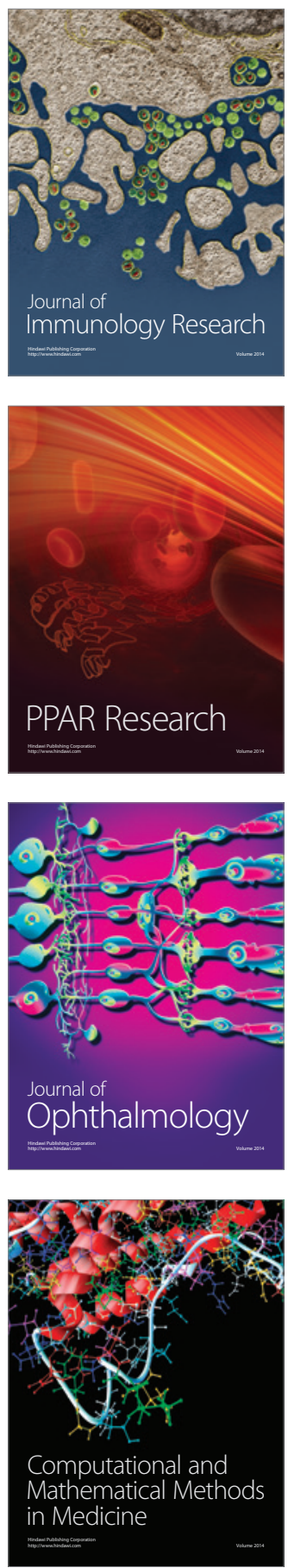

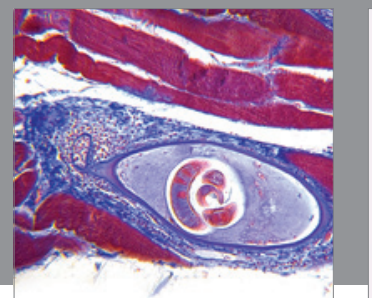

Gastroenterology

Research and Practice
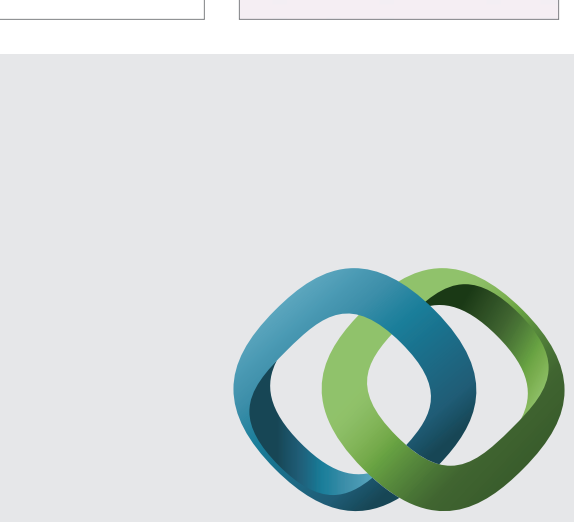

\section{Hindawi}

Submit your manuscripts at

http://www.hindawi.com
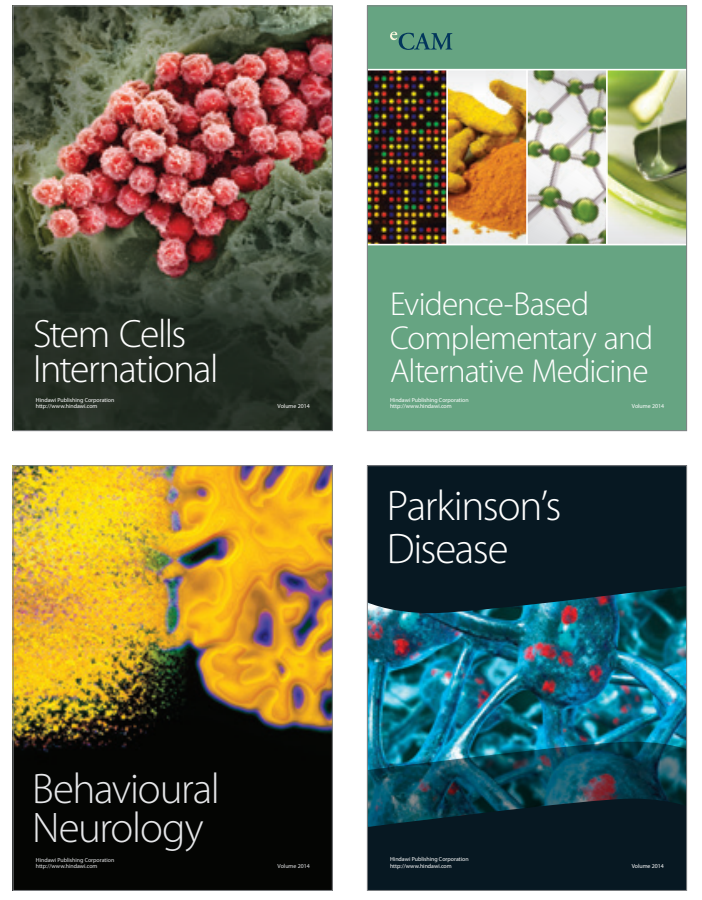
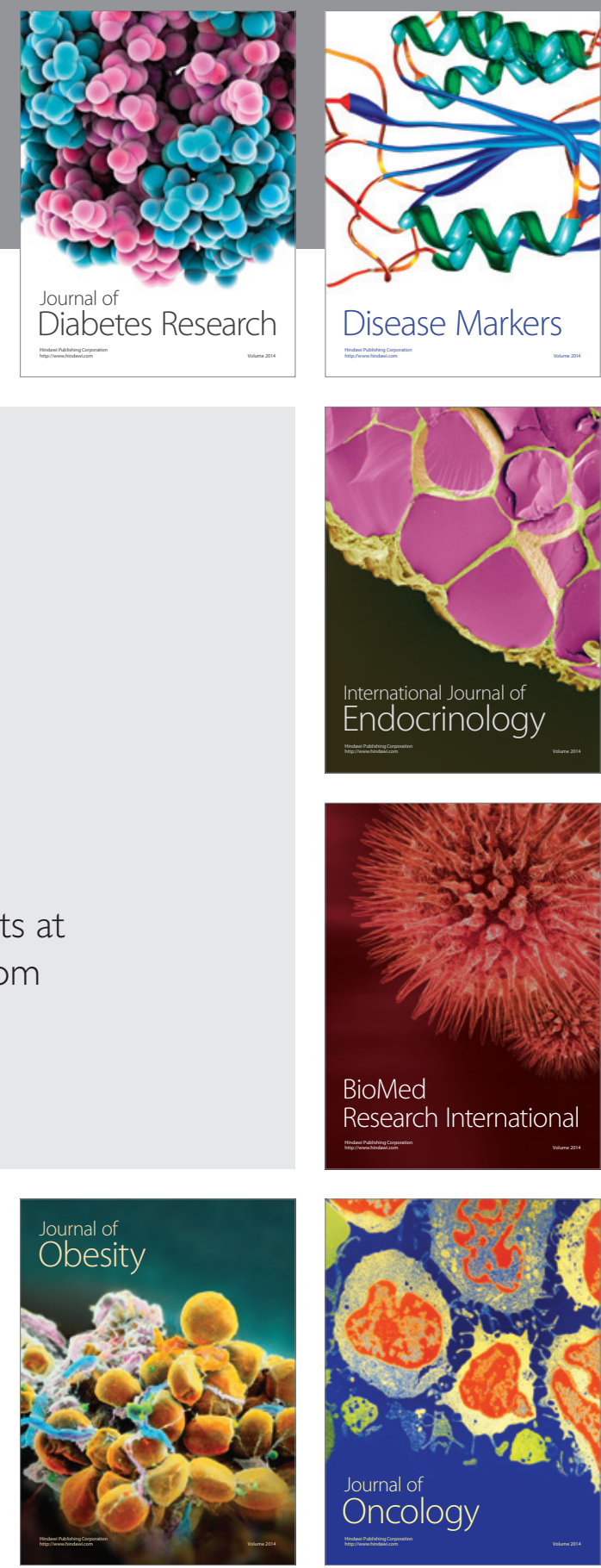

Disease Markers
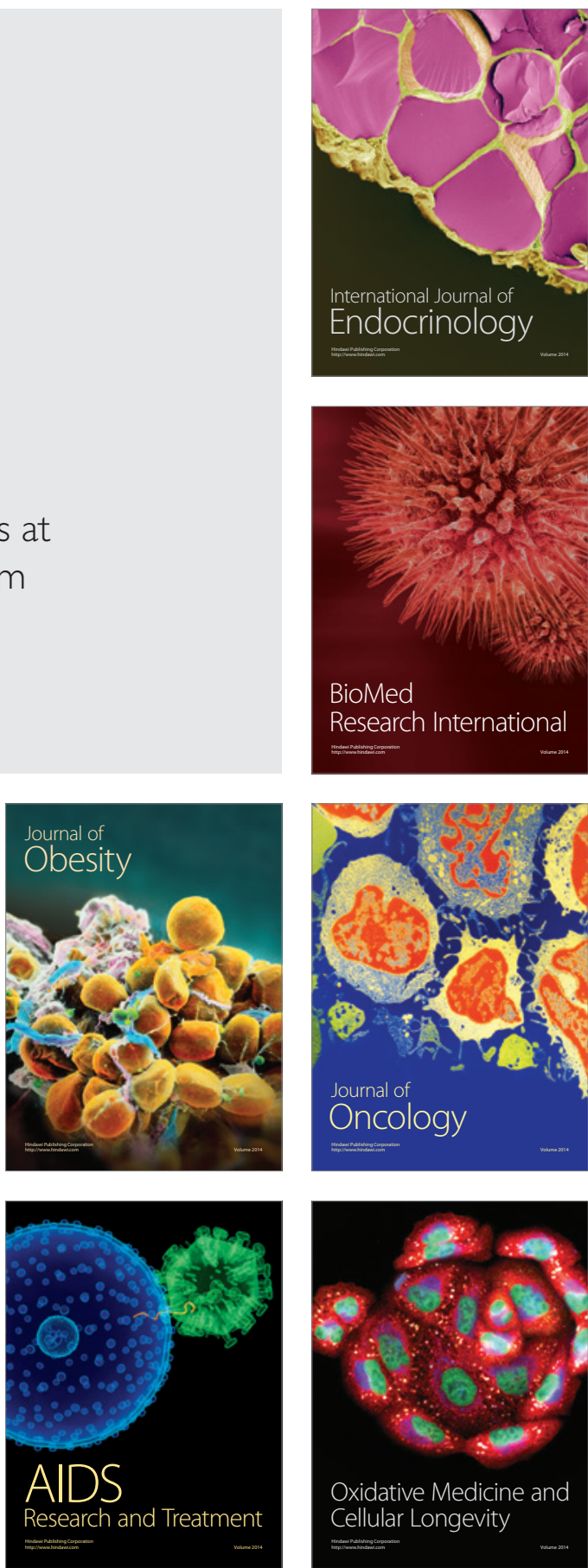